\title{
Wykształcenie zawodowe - bariera czy szansa na rynku pracy? Wyniki badania Bilans Kapitału Ludzkiego
}

DOI: $10.47050 / 65591814.102-135$

Anna Szczucka, Anna Strzebońska, Barbara Worek

Rozdział zawiera wyniki analizy sytuacji pracowników z wykształceniem zawodowym na rynku pracy w Polsce, a jego najważniejszym celem jest ocena szans rynkowych, jakie obecnie stwarza ukończenie szkoły zawodowej. Sytuację pracowników, którzy posiadają ten rodzaj wykształcenia, przedstawiono z dwóch perspektyw - pracodawców i pracowników. Scharakteryzowano poziom zgłaszanego przez pracodawców zapotrzebowania na pracowników z wykształceniem zawodowym, pojawiające się trudności rekrutacyjne, rodzaj stawianych pracownikom wymagań. Odniesiono się także do tego, jak pracodawcy postrzegają możliwości rozwoju kompetencji pracowników z wykształceniem zawodowym oraz jakie formy uczenia się uznają za właściwe dla tej grupy. Następnie z perspektywy pracowników pokazano, jak osoby z wykształceniem zawodowym radzą sobie na rynku pracy, przy uwzględnieniu poziomu zatrudnienia i jego stabilności, miejsca w hierarchii stanowisk pracy, wysokości zarobków. Zaprezentowano też, jak pracownicy oceniają przydatność wiedzy i umiejętności wyniesionych ze szkoły oraz własne kompetencje uniwersalne. $W$ rozdziale wykorzystano wyniki badania pracodawców, ludności i ofert pracy z projektu Bilans Kapitału Ludzkiego z lat 2010-2017.

\footnotetext{
Słowa kluczowe:

rynek pracy

wykształcenie zawodowe

rekrutacja pracowników

kompetencje zawodowe i ogólne
} 


\section{Vocational education - barrier or chance on the labour market? Results of the Human Capital Study}

DOI: $10.47050 / 65591814.102-135$

Anna Szczucka, Anna Strzebońska, Barbara Worek

The chapter presents the results of the analysis of the condition of people with vocational education in the labour market in Poland. Main goal is to analyse chances of people with that level of education in the labour market. Their chances are presented from two perspectives - employers and workers. In the first part, the demand for employees with vocational education is described, followed by characteristic of requirements of employers towards them, as well as the recruitment problems indicated by the employers. The first part of the chapter shows also how employers perceive the competences' development opportunities of employees with vocational education and what forms of learning they consider appropriate for this group. The second part focuses on the employees' perspective and presents how people with vocational education cope in the labour market in terms of employment level, job stability, position in the hierarchy of occupations and earnings. It also shows how those employees assess the usefulness of knowledge and skills acquired at school and their own general competences. Analyses presented in the chapter are based on the data from surveys of employers, general population and research of the job offers carried out in Study of Human Capital in Poland project in 2010-2017.

\section{Keywords:}

labour market

vocational education

recruitment process

general and job specific competences 
W tym rozdziale prezentujemy sytuację na polskim rynku pracy pod względem popytu i podaży pracowników o kwalifikacjach odpowiadających poziomowi wykształcenia zawodowego z perspektywy ogólnopolskiego badania Bilans Kapitału Ludzkiego (BKL).

Najpierw omówimy wyniki pięciu edycji badania Bilans Kapitału Ludzkiego (2010-2014)' obejmujące perspektywę popytu, czyli zapotrzebowania, jakie w tym okresie zgłaszali krajowi pracodawcy. Kluczowe kwestie, na których się koncentrujemy, to: czy na rynku jest zapotrzebowanie na pracowników z wykształceniem zawodowym? Na co zwracają uwagę pracodawcy, rekrutując pracowników? Jakie kryteria są szczególnie istotne przy zatrudnianiu wykwalifikowanych pracowników technicznych na niższe stanowiska? Co stanowi problem rekrutacyjny w przypadku pracowników z poszczególnych grup zawodowych? Jakie formy uzupełniania kompetencji są zdaniem pracodawców najbardziej skuteczne? Obraz popytu wynikający z badania pracodawców zostanie rozszerzony i uzupełniony dzięki weryfikacji wzorów rekrutacyjnych stosowanych wobec osób z wykształceniem zawodowym na podstawie analizy ofert pracy publikowanych na portalach internetowego pośrednictwa pracy oraz w powiatowych urzędach pracy w latach 2010-2014.

W drugiej części rozdziału przedstawimy sytuację osób z wykształceniem zawodowym, uwzględniając poziom ich zatrudnienia, formy zatrudnienia, dopasowanie zajmowanego stanowiska pracy do uzyskanego wykształcenia formalnego, ocenę przydatności wiedzy i umiejętności wyniesionych ze szkoły oraz ocenę własnych kompetencji uniwersalnych. Stanowi to istotny element oceny podaży kwalifikacji

Badania BKL są realizowane w ramach projektu finansowanego ze środków Europejskiego Funduszu Społecznego przez Centrum Ewaluacji i Analiz Polityk Publicznych UJ w partnerstwie z Polską Agencją Rozwoju Przedsiębiorczości. Pierwsza tura badań BKL została przeprowadzona w latach 2010-2014 i objęła ludność w wieku 18-59/64 lata, pracodawców, instytucje szkoleniowe oraz uczniów i studentów, a także analizę ofert pracy. Badania były prowadzone corocznie przez pięć lat na próbach reprezentatywnych zarówno dla całego kraju, jak i dla poszczególnych województw. Próba ludności liczyła 17,2 tys. osób rocznie, próba pracodawców 16 tys. przedsiębiorstw i instytucji rocznie, próba instytucji szkoleniowych 4,5 tys. rocznie, próba uczniów i studentów po 32 tys. rocznie (badania uczniów i studentów były przeprowadzane jednak nie corocznie, lecz jedynie dwukrotnie - w 2010 i 2014 r.). Druga tura badań BKL realizowana jest natomiast w latach 2017-2022 i obejmuje trzy podstawowe moduły - ludność, pracodawców i podmioty świadczące usługi szkoleniowo-rozwojowe. W badaniach realizowanych w latach 2016-2023 zmniejszono próby (ludność -4 tys. osób rocznie, pracodawcy $-3,5$ tys. firm i instytucji rocznie, instytucje szkoleniowe -3 tys. rocznie). W badaniach ludności podniesiono górną granicę wieku dla badanej populacji, decydując się na objęcie badaniami osób w wieku 18-69 lat. 
i kompetencji na rynku pracy, umożliwia pokazanie szans, jakie dają absolwentom szkoły zawodowe, oraz identyfikację wyzwań związanych z niedopasowaniem podaży i popytu. W tej części rozdziału będziemy posługiwać się danymi pochodzącymi z badań ludności BKL 2017.

W rozdziale posługujemy się klasyfikacją zawodów ISCO-08 opracowaną przez Międzynarodową Organizację Pracy. Została ona zastosowana we wszystkich edycjach badania BKL. Dzięki temu było możliwe porównywanie poszczególnych modułów badania, które wymagały nieco innej nomenklatury. Zważywszy na to, że szczegółowa klasyfikacja zawodów obejmuje ponad dwa tysiące zawodów i specjalności, stosujemy dwa poziomy agregacji: wielkie grupy zawodowe obejmujące dziewięć kategorii i, tam, gdzie to zasadne, bardziej szczegółową kategoryzację obejmującą trzydzieści osiem dużych grup zawodowych.

Tabela 1. Nazwy wielkich grup zawodowych stosowane w artykule

\begin{tabular}{l|l} 
skrót & \multicolumn{1}{c}{ nazwa wielkiej grupy zawodowej } \\
\hline KIER & przedstawiciele władz publicznych, wyżsi urzędnicy i kierownicy \\
\hline SPEC & specjaliści \\
\hline SRED & technicy i inny średni personel \\
\hline BIUR & pracownicy biurowi \\
\hline USLU & pracownicy usług i sprzedawcy \\
\hline ROLN ${ }^{\star}$ & rolnicy, ogrodnicy, leśnicy i rybacy \\
\hline ROBW & robotnicy przemysłowi i rzemieślnicy \\
\hline OPER & operatorzy i monterzy maszyn i urządzeń \\
\hline ROBN & pracownicy przy pracach prostych
\end{tabular}

* W badaniach pracodawców pominięto tę kategorię zawodową ze względu na charakter próby, która wykluczała gospodarstwa rolne.

Źródło: Kocór i in. 2015.

\section{Perspektywa pracodawców i ich wymagania rekrutacyjne}

\section{Wykształcenie czy doświadczenie? $\mathrm{Na}$ co zwracają uwagę pracodawcy?}

Struktura zapotrzebowania na pracowników w poszczególnych zawodach obserwowana wśród krajowych pracodawców w ramach badania BKL 2010-2014 jest relatywnie stabilna. W tym okresie najczęściej 
poszukiwaną w krajowej gospodarce grupą zawodową byli wykwalifikowani robotnicy - takie zapotrzebowanie zgłaszało $30 \%$ pracodawców spośród tych, którzy poszukiwali pracowników. Nieco mniej, ok. 21\%, poszukiwało pracowników usług lub sprzedawców, 14\% - operatorów maszyn, i ok. $8 \%$ - robotników niewykwalifikowanych. Wyniki badania wskazują więc wyraźnie, że większość poszukiwanych pracowników należy do grup zawodowych związanych najczęściej z wykształceniem zawodowym lub średnim.

Robotników wykwalifikowanych, czyli pracowników poszukiwanych najczęściej, równocześnie jest zdaniem pracodawców najtrudniej zrekrutować. Zanim jednak omówimy przyczyny trudności rekrutacyjnych, warto przyjrzeć się procesowi rekrutacji i kryteriom, które dla pracodawców są najbardziej istotne $w$ tym procesie $w$ przypadku zatrudniania pracowników z grup robotników i operatorów.

Analizując dane BKL 2010-2014, można zauważyć, że dla pracodawców wykształcenie kandydata ma ogólnie mniejsze znaczenie niż jego doświadczenie. Widoczne jest jednak bardzo duże zróżnicowanie tych oczekiwań w zależności od typu stanowiska do obsadzenia - im bardziej specjalistyczny zawód poszukiwanego pracownika, tym wykształcenie i jego poziom mają większe znaczenie w rekrutacji. W przypadku pracowników wyższego szczebla, tj. kierowników czy specjalistów, prawie $90 \%$ pracodawców podkreśla, że wykształcenie kandydata jest istotne. Takie zróżnicowanie może wynikać z faktu, że w przypadku rekrutacji specjalistów wykształcenie jest ważne $z$ dwóch powodów: potwierdza kwalifikacje, czyli warunki formalne (stopień uzyskany po ukończeniu studiów licencjackich/inżynierskich lub magisterskich), oraz niesie ze sobą informacje o sile marki dyplomu, a więc ma wartość heurystyczną, umożliwiającą preselekcję kandydatów pod względem jakości kompetencji (Antonowicz i in. 2014). W przypadku kandydatów z wykształceniem zawodowym taka możliwość jest w naszym kraju bardzo ograniczona. Dlatego pierwszeństwo doświadczenia wobec wykształcenia i zawodu w rekrutacji na takie stanowiska może wynikać z faktu, że jest ono dla pracodawców lepszą gwarancją posiadania praktycznych umiejętności i faktycznej znajomości zawodu przez kandydata.

Jednak również w obrębie analizowanej grupy zawodów (robotnicze, operatorzy i usługowe) można zaobserwować stosunkowo duże zróżnicowanie. O ile w przypadku pracodawców szukających robotników wykwalifikowanych połowa stwierdziła, że wykształcenie kandydata ma 
znaczenie, to w przypadku pracodawców poszukujących robotników niewykwalifikowanych - uważało tak już tylko $15 \%$. W tej ostatniej grupie właściwie jedynym wybijającym się kryterium jest płeć, co wynika najczęściej z fizycznego charakteru wykonywanej pracy. To kryterium jest bardzo istotne także w przypadku robotników wykwalifikowanych i operatorów. Warto jednak nadmienić, że w kontekście zmian i modernizacji kształcenia zawodowego podkreśla się, że z uwagi na rozwój technologii i coraz mniejszy komponent siły fizycznej koniecznej do wykonywania pracy w zawodach technicznych, znaczenie tego kryterium powinno maleć2.

Tabela 2. Oczekiwania pracodawców wobec kandydatów do pracy-znaczenie

wykształcenia, zawodu, doświadczenia, płci i znajomości języków obcych (w \%)

\begin{tabular}{l|c|c|c|c|c} 
wielka grupa ISCO-08 & wykształcenie & zawód & doświadczenie & płeć & język \\
\hline kierowcy & 88 & nd & 91 & 48 & 42 \\
\hline specjaliści & 84 & nd & 59 & 31 & 66 \\
\hline technicy i inny średni personel & 71 & 56 & 66 & 47 & 46 \\
\hline pracownicy biurowi & 64 & 36 & 39 & 59 & 50 \\
\hline pracownicy usług i sprzedawcy & 53 & 56 & 53 & 64 & 42 \\
\hline robotnicy przemysłowi i rzemieślnicy & 46 & 74 & 79 & 91 & 15 \\
\hline operatorzy i monterzy maszyn i urządzeń & 34 & 51 & 72 & 88 & 34 \\
\hline pracownicy przy pracach prostych & 19 & 43 & 48 & 83 & 7 \\
\hline ogółem* & 57 & 60 & 65 & 66 & 38
\end{tabular}

* udział procentowy danej odpowiedzi dla wszystkich badanych (tzw. przeciętny profil

kolumnowy).

Źródło: opracowanie własne na podstawie badania pracodawców BKL - dane zagregowane

z edycji 2010-2014.

W przypadku poszukiwania pracowników z grup zawodów bardziej wyspecjalizowanych, tj. robotników wykwalifikowanych i operatorów maszyn, liczy się już nie tylko płeć (choć pozostaje najistotniejszym kryterium dla pracodawców). Bardzo ważne staje się także doświadczenie pracownika, którego wymaga dziewięciu na dziesięciu pracodawców, a w następnej kolejności wyuczony zawód kandydata.

$2 \quad$ Por. podsumowanie konferencji „Rynek pracy wyzwaniem, kształcenie zawodowe szansą” zorganizowanej przez Polsko-Niemiecką Izbę Przemysłowo-Handlową pod patronatem Ministerstwa Edukacji Narodowej i Ministerstwa Rozwoju w dniu 11 września 2017 r. www.kas.de [dostęp: 2.11.2018]. 
Takie wnioski potwierdza także analiza długości doświadczenia, którego pracodawcy oczekują od kandydatów. Poza stanowiskami kierowniczymi, na które pracodawcy wymagali prawie trzyletniego stażu, najdłuższym doświadczeniem musieli wykazać się właśnie kandydaci na stanowiska robotników wykwalifikowanych - średnio około dwóch lat. Mniejszego doświadczenia wymagano na stanowiskach o wyższych kwalifikacjach, jak w przypadku specjalistów czy techników, a także od osób rekrutowanych na stanowiska biurowe i usługowe, czyli wymagające mniejszej specjalizacji zawodowej.

Wykres 1. Średnia długość wymaganego przez pracodawców doświadczenia (w latach) w podziale na szerokie kategorie zawodowe

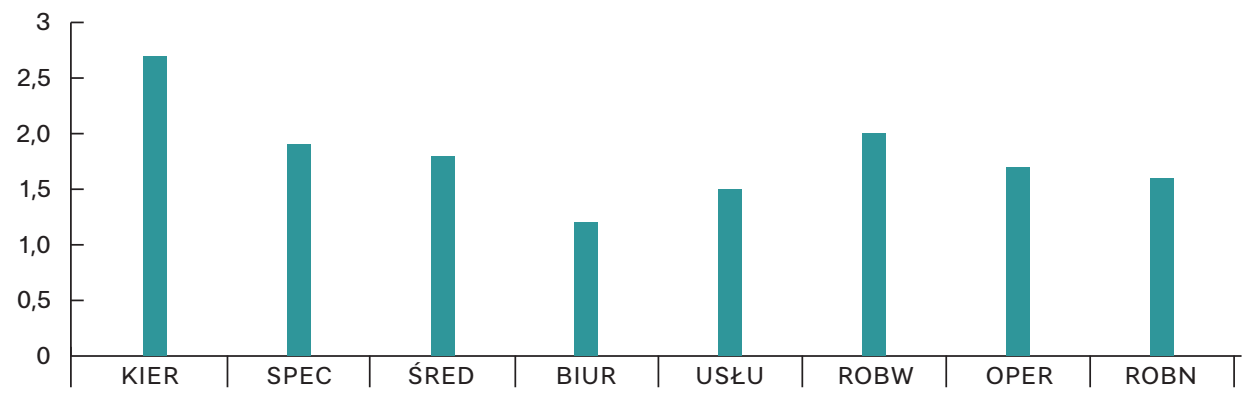

Źródło: opracowanie własne na podstawie badania pracodawców BKL - dane zagregowane z edycji 2010-2014. 
Wykres 2. Średnia długość wymaganego przez pracodawców doświadczenia (w latach)

dla wybranych grup zawodowych

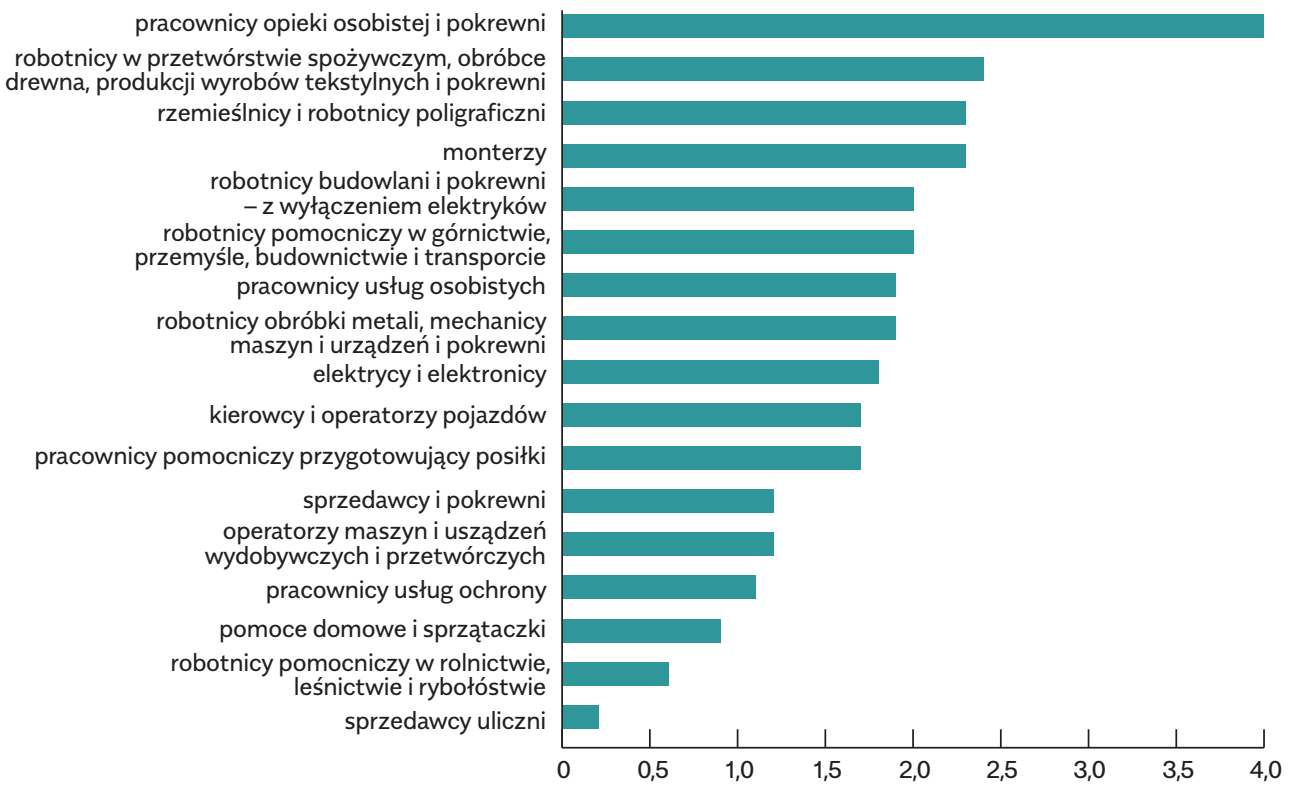

Źródło: opracowanie własne na podstawie badania pracodawców BKL - dane zagregowane z edycji 2010-2014.

Ogólne wymagania pracodawców wobec kandydatów w zakresie poziomu wykształcenia pozostają zgodne z intuicją. Wykształcenie wyższe, najlepiej magisterskie, warunkuje pracę na stanowisku kierownika czy specjalisty (odpowiednio, $41 \%$ i $45 \%$ pracodawców wymagało tytułu magistra, a kolejne 32-38\% co najmniej tytułu licencjata). Wykształcenie średnie zapewnia pracę w zawodach biurowych i usługowych, natomiast zasadnicze zawodowe pracę jako robotnik niewykwalifikowany. W przypadku robotników wykwalifikowanych wymagania pracodawców różnicowała grupa zawodowa, np. w przypadku robotników w przetwórstwie spożywczym, obróbce drewna, produkcji wyrobów tekstylnych i pokrewnych pracodawcy preferowali wykształcenie zasadnicze zawodowe (83\%), ale w przypadku np. elektryków i elektroników czy kierowców dominował wymóg wykształcenia średniego. 
Tabela 3. Wymagania pracodawców wobec poziomu wykształcenia kandydatów ubiegających się o pracę z wybranych grup zawodowych (odsetek wskazań)

\begin{tabular}{|c|c|c|c|c|c|c|}
\hline & \multicolumn{5}{|c|}{ Poziom wykształcenia } & \multirow[b]{2}{*}{$\mathrm{N}$} \\
\hline & podstawowe & \begin{tabular}{|l|} 
zasadnicze \\
zawodowe
\end{tabular} & średnie & $\begin{array}{c}\text { wyższe } \\
\text { licencjackie }\end{array}$ & $\begin{array}{c}\text { wyższe } \\
\text { magisterskie }\end{array}$ & \\
\hline pracownicy usług osobistych & 1 & 44 & 51 & 4 & 0 & 507 \\
\hline sprzedawcy i pokrewni & 0 & 13 & 66 & 15 & 6 & 687 \\
\hline $\begin{array}{l}\text { pracownicy opieki osobistej } \\
\text { i pokrewni }\end{array}$ & 0 & 0 & 39 & 8 & 54 & 39 \\
\hline $\begin{array}{l}\text { robotnicy budowlani } \\
\text { i pokrewni }\end{array}$ & 1 & 74 & 24 & 0 & 1 & 581 \\
\hline $\begin{array}{l}\text { robotnicy obróbki metali, } \\
\text { mechanicy maszyn i urządzeń }\end{array}$ & 0 & 55 & 42 & 3 & 0 & 460 \\
\hline $\begin{array}{l}\text { rzemieślnicy i robotnicy } \\
\text { poligraficzni }\end{array}$ & 0 & 50 & 50 & 0 & 0 & 14 \\
\hline elektrycy i elektronicy & 0 & 27 & 65 & 4 & 4 & 241 \\
\hline $\begin{array}{l}\text { robotnicy w przedwórstwie } \\
\text { spożywczym, obróbce drewna, } \\
\text { wyrobów tekstylnych }\end{array}$ & 2 & 83 & 16 & & 0 & 194 \\
\hline operatorzy maszyn i urządzeń & 0 & 51 & 48 & 0 & 1 & 73 \\
\hline monterzy & 0 & 18 & 64 & 14 & 4 & 28 \\
\hline $\begin{array}{l}\text { kierowcy i operatorzy } \\
\text { pojazdów }\end{array}$ & 1 & 34 & 64 & 0 & 1 & 413 \\
\hline $\begin{array}{l}\text { robotnicy pomocniczy } \\
\text { w górnictwie, przemyśle, } \\
\text { budownictwie i transporcie }\end{array}$ & 0 & 65 & 35 & 0 & 0 & 60 \\
\hline $\begin{array}{l}\text { pracownicy pomocniczy } \\
\text { przygotowujący posiłki }\end{array}$ & 13 & 53 & 33 & 0 & 0 & 15 \\
\hline
\end{tabular}

Źródło: opracowanie własne na podstawie badania pracodawców

BKL - dane zagregowane z edycji 2010-2014.

\section{Umiejętności czy motywacja - co powoduje trudności w rekrutacji pracowników?}

Wyniki wszystkich edycji badania BKL wskazują, że największe trudności rekrutacyjne występują w przypadku robotników wykwalifikowanych, w szczególności budowlanych oraz wykwalifikowanych pracowników obróbki metali i mechaników maszyn ( $16 \%$ i $9 \%$ ), a także sprzedawców (12\%) oraz kierowców i operatorów pojazdów (12\%). Odsetek pracodawców wskazujących na trudności w poszczególnych grupach zawodowych przedstawiono w Tabeli 4. Ogólnie trudności ze zrekrutowaniem robotników wykwalifikowanych zgłasza aż co trzeci pracodawca (33\%). Kolejne $20 \%$ ma problemy w zrekrutowaniu pracowników usług i sprzedawców, a 14\% - operatorów. Wskazuje to za- 
tem na istotne niedopasowanie podaży pracowników do oczekiwań pracodawców. Jakie są tego przyczyny?

Tabela 4. Wybrane zawody, w przypadku których pracodawcy w latach 2010-2014

zgłaszali największe trudności ze znalezieniem odpowiednich pracowników

(odsetek pracodawców doświadczających trudności rekrutacyjnych)*

\begin{tabular}{l|c|c} 
& $\%$ & $\mathrm{~N}$ \\
\hline robotnicy budowlani i pokrewni - z wyłączeniem elektryków & 16 & 2048 \\
\hline sprzedawcy i pokrewni & 12 & 1551 \\
\hline kierowcy i operatorzy pojazdów & 12 & 1520 \\
\hline robotnicy obróbki metali, mechanicy maszyn i urządzeń i pokrewni & 9 & 1170 \\
\hline średni personel do spraw biznesu i administracji & 8 & 1118 \\
\hline pracownicy usług osobistych & 8 & 1118 \\
\hline robotnicy w przedwórstwie spożywczym, obróbce drewna, wyrobów tekstylnych & 6 & 733 \\
\hline ipokrewni & 5 & 653 \\
\hline elektrycy i elektronicy & 4 & 578 \\
\hline specjaliści nauk fizycznych, matematycznch i technicznych & 4 & 590 \\
\hline specjaliści do spraw zdrowia & 4 & 529 \\
\hline specjaliści do spraw ekonomicznych i zarządzania & 3 & 388 \\
\hline specjaliści do spraw technologii informacyjno-komunikacyjnych & 3 & 355 \\
\hline średni personel nauk fizycznych, chemicznych i technicznych & 3 & 406 \\
\hline robotnicy pomocniczy w górnictwie, przemyśle, budownictwie i transporcie & 2 & 282 \\
\hline specjaliści nauczania i wychowania & 2 & 200 \\
\hline specjaliści z dziedziny prawa, dziedzin społecznych i kultury & 2 & 211 \\
\hline średni personel z dziedziny prawa, spraw społecznych, kultury i pokrewny & 2 & 275 \\
\hline sekretarki, operatorzy urządzeń biurowych i pokrewni & 2 & 216
\end{tabular}

*Ankietowani mogli wskazać więcej niż jedną odpowiedź.

Źródło: opracowanie własne na podstawie badania pracodawców

$\mathrm{BKL}$ - dane zagregowane z edycji 2010-2014.

Kluczową przyczyną trudności, podawaną przez 80-90\% pracodawców (w zależności od oferowanego stanowiska), jest to, że kandydaci zgłaszający się do pracy nie spełniają oczekiwań pracodawcy. Choć należy zaznaczyć, że akurat w przypadku zawodów dla robotników wykwalifikowanych pracodawcy mają częściej niż w innych grupach problem z niedoborem ilościowym, czyli brakiem jakichkolwiek zgłoszeń na oferowane stanowiska (12\% pracodawców szukających pracowników).

W przypadku kandydatów na stanowiska robotników wykwalifikowanych, którzy nie spełniali oczekiwań pracodawców, kluczowym problemem był niedobór odpowiednich kompetencji (36\%), a w drugiej kolejności brak doświadczenia (28\%). Problem niewystarczające- 
go doświadczenia dominował (35\%) z kolei w przypadku operatorów i monterów. W tej grupie częściej niż w innych barierą był też brak wymaganych kwalifikacji, czyli odpowiednich uprawnień i licencji (14\%). Warto zwrócić na to uwagę, zwłaszcza że wyniki badań wskazują, że problem ten narasta ${ }^{3}$ i może wiązać się z koniecznością przyjrzenia się regulacjom i procesowi certyfikacji pewnych kompetencji, aby nie utrudniać pracodawcom rekrutacji niezbędnych pracowników (Kocór i in. 2015).

W przypadku robotników niewykwalifikowanych mamy do czynienia z niewystarczającą motywacją do pracy - wskazuje na nią ponad połowa pracodawców szukających pracowników w tej grupie. Jest to istotny problem także w przypadku pracowników usług i sprzedawców. Występuje on na równi z problemem niedoborów kompetencyjnych w tej kategorii pracowników (odpowiednio, 34\% i 37\%).

Tabela 5. Powody niespełniania oczekiwań pracodawców przez kandydatów do pracy (dane w procentach w podziale na duże grupy zawodowe w klasyfikacji ISCO-08)

\begin{tabular}{l|c|c|c|c|c|c} 
& $\begin{array}{c}\text { brak } \\
\text { odpowiednich } \\
\text { kompetencji }\end{array}$ & $\begin{array}{c}\text { brak } \\
\text { wymaganych } \\
\text { uprawnień }\end{array}$ & $\begin{array}{c}\text { brak } \\
\text { odpowiedniego } \\
\text { doświadczenia }\end{array}$ & $\begin{array}{c}\text { brak } \\
\text { motywacji } \\
\text { do pracy }\end{array}$ & $\begin{array}{c}\text { z innych } \\
\text { powodów }\end{array}$ & N \\
\hline KIER & 41 & 7 & 29 & 16 & 8 & 275 \\
\hline SPEC & 42 & 15 & 20 & 12 & 12 & 2107 \\
\hline ŚRED & 41 & 10 & 26 & 21 & 3 & 1554 \\
\hline BIUR & 37 & 6 & 19 & 32 & 7 & 523 \\
\hline USŁU & 37 & 3 & 22 & 34 & 4 & 2388 \\
\hline ROBW & 36 & 7 & 28 & 25 & 5 & 3985 \\
\hline OPER & 25 & 14 & 35 & 20 & 6 & 1600 \\
\hline ROBN & 21 & 5 & 16 & 55 & 2 & 668 \\
\hline ogółem & 36 & 8 & 25 & 25 & 6 & 13100
\end{tabular}

\footnotetext{
* Oznacza udział procentowy danej odpowiedzi dla wszystkich

badanych (tzw. przeciętny profil kolumnowy).

Źródło: opracowanie własne na podstawie badania pracodawców

$\mathrm{BKL}$ - dane zagregowane z edycji 2010-2014.
}

W zakresie niedoborów kompetencyjnych kandydatów, które utrudniają pracodawcom rekrutację odpowiednich pracowników, wyróżniają 
się przede wszystkim kompetencje zawodowe. Na ich niedopasowanie do potrzeb wskazuje co drugi rekrutujący pracodawca. Niedobory te są najbardziej dotkliwe w grupach zawodów, w których kompetencje są zdobywane najczęściej w ramach szkolnictwa zawodowego. W przypadku robotników wykwalifikowanych na braki w umiejętnościach zawodowych wskazuje aż $63 \%$ pracodawców i-obserwując zmiany w tym obszarze w kolejnych edycjach badania - zjawisko to narasta. Warto zauważyć, że wśród kandydatów na stanowiska robotników wykwalifikowanych pracodawcy dostrzegali nawet niedobór ogólnych kompetencji technicznych (16\%).

W przypadku operatorów i monterów niedobory umiejętności zawodowych dostrzega 55\% rekrutujących pracodawców, w przypadku zawodów usługowych - 52\%, a wśród rekrutujących na stanowiska robotników niewykwalifikowanych aż 53\% pracodawców.

W przypadku kompetencji ogólnych najbardziej deficytowe są zdaniem pracodawców kompetencje samoorganizacyjne, czyli zdolność do samodzielnego organizowania pracy, rozplanowania i terminowej realizacji działań, skuteczność w dążeniu do celu czy przejawianie inicjatywy. Warto podkreślić, że deficyt kompetencji samoorganizacyjnych ma zdaniem pracodawców charakter horyzontalny, czyli dotyczy kandydatów niezależnie od rodzaju stanowiska, na które aplikują. Niemniej jednak w przypadku zawodów na szczeblu poniżej średniego personelu stanowi on większy i częstszy problem.

Drugim typem horyzontalnie deficytowych kompetencji ogólnych są kompetencje interpersonalne, przy czym tendencja w tym przypadku jest odwrotna - w przypadku zawodów robotniczych i operatorów są one rzadziej wskazywane jako kluczowe braki niż w przypadku innych grup, w szczególności usługowych i biurowych. W tych zawodach kompetencje takie jak komunikatywność czy umiejętność współpracy w grupie są bardziej istotne niż w zawodach robotniczych, stąd ich niedobory stanowią dla pracodawców większe wyzwanie rekrutacyjne. 
Tabela 6. Niedobory kompetencyjne kandydatów z dużych grup zawodowych w klasyfikacji ISCO-08 w opinii pracodawców doświadczających trudności rekrutacyjnych (odsetek wskazań konkretnych kompetencji i cech)*

\begin{tabular}{|c|c|c|c|c|c|c|c|c|c|}
\hline & KIER & SPEC & ŚRED & BIUR & USŁU & ROBW & OPER & ROBN & ogółem ** \\
\hline $\begin{array}{l}\text { kompetencje } \\
\text { zawodowe }\end{array}$ & 42 & 39 & 50 & 14 & 52 & 63 & 55 & 53 & 52 \\
\hline $\begin{array}{l}\text { kompetencje } \\
\text { samoorganizacyjne }\end{array}$ & 29 & 22 & 22 & 32 & 30 & 24 & 32 & 33 & 26 \\
\hline $\begin{array}{l}\text { kompetencje } \\
\text { interpersonalne }\end{array}$ & 6 & 16 & 15 & 27 & 32 & 3 & 11 & 13 & 14 \\
\hline $\begin{array}{l}\text { kompetencje } \\
\text { techniczne }\end{array}$ & 2 & 3 & 6 & 4 & 6 & 16 & 12 & 7 & 9 \\
\hline kwalifikacje & 6 & 11 & 8 & 4 & 4 & 9 & 12 & 5 & 8 \\
\hline $\begin{array}{l}\text { kompetencje } \\
\text { kognitywne }\end{array}$ & 20 & 5 & 8 & 13 & 6 & 6 & 5 & 14 & 7 \\
\hline $\begin{array}{l}\text { kompetencje } \\
\text { komputerowe }\end{array}$ & 2 & 21 & 8 & 14 & 5 & 2 & 2 & 2 & 7 \\
\hline $\begin{array}{l}\text { znajomość } \\
\text { języków obcych }\end{array}$ & 9 & 7 & 8 & 17 & 5 & 1 & 4 & 0 & 5 \\
\hline $\begin{array}{l}\text { kompetencje } \\
\text { fizyczne }\end{array}$ & 0 & 1 & 5 & 0 & 4 & 5 & 8 & 8 & 4 \\
\hline kompetencje inne & 1 & 4 & 4 & 1 & 4 & 4 & 8 & 4 & 4 \\
\hline $\begin{array}{l}\text { kompetencje } \\
\text { kierownicze }\end{array}$ & 17 & 1 & 3 & 5 & 2 & 3 & 0 & 6 & 3 \\
\hline dyspozycyjność & 0 & 2 & 3 & 11 & 5 & 2 & 5 & 9 & 3 \\
\hline $\begin{array}{l}\text { kompetencje } \\
\text { kulturalne }\end{array}$ & 0 & 6 & 3 & 2 & 1 & 1 & 1 & 5 & 2 \\
\hline $\begin{array}{l}\text { kompetencje } \\
\text { biurowe }\end{array}$ & 6 & 3 & 5 & 8 & 1 & 0 & 2 & 0 & 2 \\
\hline $\begin{array}{l}\text { kompetencje } \\
\text { matematyczne }\end{array}$ & 4 & 0 & 4 & 4 & 2 & 0 & 1 & 0 & 2 \\
\hline $\mathrm{N}$ & 99 & 695 & 539 & 151 & 738 & 1275 & 332 & 112 & 3941 \\
\hline
\end{tabular}

* Ankietowani mogli wskazać więcej niż jedną odpowiedź.

** Oznacza udział procentowy danej odpowiedzi dla wszystkich badanych (tzw. przeciętny profil kolumnowy).

Źródło: opracowanie własne na podstawie badania pracodawców BKL - dane zagregowane z edycji 2010-2014.

Powyższe analizy można podsumować następująco - pracodawcy podkreślają występowanie deficytu zwłaszcza w wypadku tych kompetencji, które są kluczowe do pracy na danych stanowiskach. W przypadku interesujących nas grup zawodów zasadniczą kwestią jest więc wyzwanie związane z niedoborami kompetencji stricte zawodowych, w tym związanych z uprawnieniami (w szczególności w przypadku operatorów i monterów), a także samoorganizacyjnych. W tym kontekście warto zwrócić uwagę na problem możliwości uzupełniania 
tych deficytów już w miejscu pracy. Z punktu widzenia pracodawców bardziej zasadne jest zatrudnienie osoby nawet o niższych kompetencjach zawodowych, ale lepiej zorganizowanej, nauczonej terminowości i bardziej kontaktowej, ponieważ kompetencje zawodowe związane $z$ danym stanowiskiem łatwiej uzupełnić w miejscu pracy (nie dotyczy to oczywiście uprawnień i kwalifikacji zawodowych). Pracodawcy często $w$ momencie rekrutacji dopuszczają konieczność niewielkiego doszkolenia pracownika już po jego zatrudnieniu. Pytani o najbardziej ich zdaniem efektywne formy uzupełniania czy podnoszenia kompetencji w zależności od stanowiska pracownika wskazują, że w przypadku kadry niższego szczebla najbardziej skuteczne są: bezpośrednia nauka pod kierunkiem innej osoby/przełożonego, obserwacja innej osoby w miejscu pracy (job shadowing) oraz instruktaże dotyczące obsługi sprzętu, maszyn czy oprogramowania na stanowisku pracy (wykres 3). W takim systemie, z punktu widzenia pracodawców, racjonalne jest rozwijanie kompetencji pracowników w odniesieniu do firmowego know-how i specyfiki samego stanowiska pracy już po zatrudnieniu, ale trudno uznać za zasadne i możliwe uzupełnianie w taki sposób kompetencji ogólnych kandydatów.

Wykres 3. Najskuteczniejsze zdaniem pracodawców formy rozwoju kompetencji

według rodzaju stanowiska (w \%)

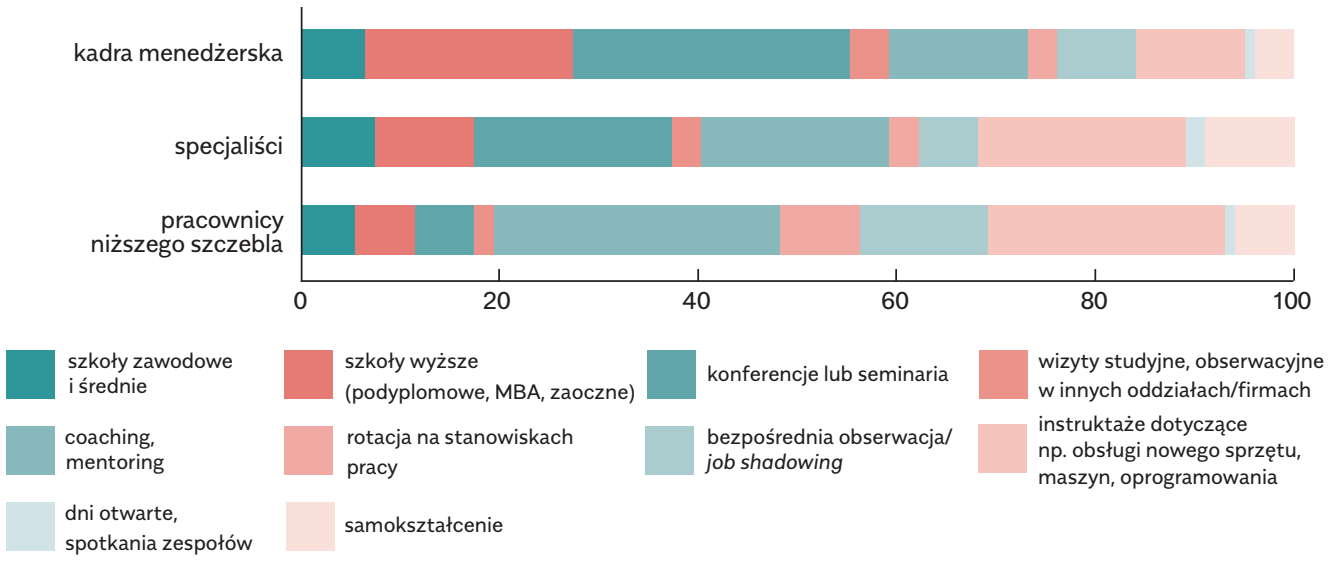

${ }^{*} \mathrm{~N}=309$ dla firm 50+, $\mathrm{N}=1595$ dla firm 1-49.

Źródło: BKL, badania pracodawców 2017. 
Wzory rekrutacyjne stosowane wobec osób z wyksztalceniem zawodowym w ofertach pracy

Obraz popytu wynikający z badania pracodawców warto rozszerzyć i uzupełnić dzięki analizie ofert pracy, gdyż jedną z pierwszych aktywności w procesie poszukiwania zatrudnienia jest przegląd tego typu ogłoszeń, będących nośnikiem wymagań pracodawców wobec kandydatów do pracy. Analiza treści ofert pracy pozwala prześledzić możliwe ścieżki rozwoju kariery zawodowej, a także funkcjonujące na rynku pracy wzory rekrutacyjne stosowane wobec osób z wykształceniem zawodowym, które odpowiada wykształceniu, jakie uzyskuje się obecnie w szkołach branżowych ${ }^{4}$.

Prezentowane wyniki analizy ofert pracy opierają się na materiale źródłowym projektu Bilans Kapitału Ludzkiego, w ramach którego zebrano oferty pracy publikowane na portalach internetowego pośrednictwa pracy oraz w powiatowych urzędach pracy w latach 2010-20145. Większość analizowanych ofert pracy zawierała następujące informacje:

$\rightarrow$ Nazwę stanowiska pracy/zawodu: informacje tego typu zostały zakodowane zgodnie z klasyfikacją ISCO-08 i są prezentowane na poziomie dużych grup zawodowych wraz z numerem odpowiadającym dużej kategorii zawodowej ISCO-08;

$\rightarrow$ Poziom wykształcenia kandydatów: oczekiwany w danej grupie zawodowej poziom i niekiedy kierunek wykształcenia6;

$\rightarrow$ Doświadczenie kandydatów: średnia długość stażu zawodowego wymagana w danej grupie zawodowej, konieczność posiadania dokumentów potwierdzających deklarowaną długość doświadczenia oraz referencji przynajmniej z ostatniego miejsca pracy;

$\rightarrow$ Kompetencje kandydatów: rozumiane jako specjalistyczna wiedza, umiejętności i chęć do wykonywania pracy, zagregowane zgodnie z przyjętą w badaniu BKL dwupoziomową klasyfikacją kompetencji (Strzebońska, Dobrzyńska 2011, s. 31); 
$\rightarrow$ Dodatkowe wymagania wobec kandydatów: pojawiające się oczekiwania odnośnie do kwalifikacji, np. prawo jazdy, niekaralność, kursy specjalistyczne.

Gdy analizuje się możliwe ścieżki kariery absolwentów szkół zawodowych, warto pamiętać, że oferty pracy skierowane do kandydatów legitymujących się średnim i niższym poziomem wykształcenia znacznie częściej umieszczane są przez pracodawców w powiatowych urzędach pracy niż na portalach internetowego pośrednictwa pracy (Kocór i in. 2015). Wybór miejsca publikacji oferty ma znaczenie dla jej treści: ogłoszenia zamieszczane na portalach internetowego pośrednictwa pracy są dłuższe, gdyż rekrutujący ma większą swobodę w formułowaniu swoich oczekiwań wobec kandydatów do pracy w porównaniu do ogłoszeń właściwych dla powiatowych urzędów pracy. Publiczne służby zatrudnienia dopasowują wymagania pracodawców do obowiązujących w urzędach formularzy, które zawierają przede wszystkim pytania o dane na temat rekrutowanego zawodu, kwalifikacji (dokumentów formalnie potwierdzających poziom wykształcenia, prawa jazdy itd.) czy doświadczenia zawodowego osób mogących ubiegać się o zatrudnienie.

Poszukując wzorów rekrutacyjnych, w pierwszej kolejności prześledzimy, na jakie stanowiska rekrutowane są osoby z wykształceniem zawodowym. Tabela 7 zawiera wykaz grup zawodowych, w których zidentyfikowano oferty pracy skierowane do kandydatów posiadających świadectwo ukończenia szkoły zawodowej. Pod względem popularności najwięcej ogłoszeń o pracę dotyczyło naboru na wykwalifikowane stanowiska przeznaczone dla robotników przemysłowych i rzemieślników (przede wszystkim elektryków i elektroników, robotników obróbki metali, mechaników maszyn i urządzeń), a także dla operatorów oraz monterów maszyn i urządzeń ( $w$ tym zwłaszcza monterów). W odniesieniu do tych grup zawodowych pracodawcy najczęściej oczekiwali wykształcenia zawodowego. Podobne wymagania odnośnie do poziomu wykształcenia sformułowano w ofertach skierowanych do pracowników pomocniczych przygotowujących posiłki (prawie 1/3 z nich zawierała wymóg zawodowego wykształcenia kierunkowego aplikantów) oraz do pracowników usług osobistych (dotyczy to $1 / 4$ ogłoszeń z puli przeznaczonej dla tej grupy zawodowej). Oczywiście w puli analizowanych ogłoszeń znalazły się również oferty rekrutacyjne dla pracowników usług (np. pracowników usług ochrony) i sprzedawców 
czy też dla pracowników biurowych oraz techników i innego średniego personelu z wykształceniem zawodowym. Niemniej ogłoszenia tego typu nie miały powszechnego charakteru.

Tabela 7. Wykaz dużych grup zawodowych w klasyfikacji ISCO-08, w jakich najczęściej zidentyfikowano oferty pracy skierowane do kandydatów posiadających świadectwo ukończenia szkoły zawodowej (w \%)

\begin{tabular}{|c|c|c|c|c|}
\hline \multirow{2}{*}{$\begin{array}{l}\text { Kod } \\
\text { ISCO-08 }\end{array}$} & \multirow[b]{2}{*}{ Grupa zawodowa } & \multicolumn{2}{|c|}{ Wykształcenie (\% ofert) } & \multirow[b]{2}{*}{$\mathrm{N}$} \\
\hline & & $\begin{array}{l}\text { zasadniczo } \\
\text { zawodowe }\end{array}$ & nie określono & \\
\hline 8.82 & operatorzy i monterzy maszyn i urządzeń: monterzy & 50 & 43 & 220 \\
\hline 7.74 & $\begin{array}{l}\text { robotnicy przemysłowi i rzemieślnicy: elektrycy i elek- } \\
\text { tronicy }\end{array}$ & 45 & 40 & 1489 \\
\hline 7.72 & $\begin{array}{l}\text { robotnicy przemysłowi i rzemieślnicy: robotnicy } \\
\text { obróbki metali, mechanicy maszyn i urządzeń }\end{array}$ & 41 & 49 & 3138 \\
\hline 7.73 & $\begin{array}{l}\text { robotnicy przemysłowi i rzemieślnicy: rzemieślnicy } \\
\text { i robotnicy poligraficzni }\end{array}$ & 39 & 36 & 190 \\
\hline 7.75 & $\begin{array}{l}\text { robotnicy przemysłowi i rzemieślnicy: robotnicy } \\
\text { w przetwórstwie spożywczym, obróbce drewna, pro- } \\
\text { dukcji wyrobów tekstylnych }\end{array}$ & 38 & 57 & 2135 \\
\hline 8.81 & $\begin{array}{l}\text { operatorzy i monterzy maszyn i urządzeń: operatorzy } \\
\text { maszyn i urządzeń wydobywczych i przetwórczych }\end{array}$ & 33 & 49 & 638 \\
\hline 8.83 & $\begin{array}{l}\text { operatorzy i monterzy maszyn i urządzeń: kierowcy } \\
\text { i operatorzy pojazdów }\end{array}$ & 33 & 60 & 3792 \\
\hline 7.71 & $\begin{array}{l}\text { robotnicy przemysłowi i rzemieślnicy: robotnicy bu- } \\
\text { dowlani - z wyłączeniem elektryków }\end{array}$ & 31 & 60 & 3857 \\
\hline 9.94 & $\begin{array}{l}\text { pracownicy przy pracach prostych: pracownicy przygo- } \\
\text { towujący posiłki }\end{array}$ & 31 & 56 & 323 \\
\hline 5.51 & $\begin{array}{l}\text { pracownicy usług i sprzedawcy: pracownicy usług } \\
\text { osobistych }\end{array}$ & 26 & 59 & 3868 \\
\hline 9.93 & $\begin{array}{l}\text { pracownicy przy pracach prostych: robotnicy pomocni- } \\
\text { czy w górnictwie, przemyśle, budownictwie i transpo- } \\
\text { rcie }\end{array}$ & 19 & 65 & 1022 \\
\hline 5.54 & $\begin{array}{l}\text { pracownicy usług i sprzedawcy: pracownicy usług } \\
\text { ochrony }\end{array}$ & 17 & 62 & 874 \\
\hline 9.96 & $\begin{array}{l}\text { pracownicy przy pracach prostych: ładowacze nieczy- } \\
\text { stości i inni pracownicy przy pracach prostych }\end{array}$ & 15 & 67 & 315 \\
\hline 4.43 & $\begin{array}{l}\text { pracownicy biurowi: pracownicy do spraw finansowo- } \\
\text {-statystycznych i ewidencji materiałowej }\end{array}$ & 13 & 49 & 1124 \\
\hline 5.52 & pracownicy usług i sprzedawcy: sprzedawcy & 9 & 50 & 7518 \\
\hline 3.34 & $\begin{array}{l}\text { technicy i inny średni personel: średni personel z dzie- } \\
\text { dziny prawa, spraw społecznych, kultury }\end{array}$ & 6 & 51 & 509 \\
\hline 9.91 & $\begin{array}{l}\text { pracownicy przy pracach prostych: pomoce domowe } \\
\text { i sprzątaczki }\end{array}$ & 6 & 70 & 1003 \\
\hline 3.31 & $\begin{array}{l}\text { technicy i inny średni personel: średni personel nauk } \\
\text { fizycznych, chemicznych i technicznych }\end{array}$ & 5 & 27 & 1550 \\
\hline 4.42 & pracownicy biurowi: pracownicy obsługi klienta & 3 & 52 & 1630 \\
\hline
\end{tabular}

Dane nie sumują się do $100 \%$, ponieważ pracodawcy wskazywali także inne wymagania wobec wykształcenia kandydatów.

Źródło: opracowanie własne na podstawie danych BKL, badanie ofert pracy 2010-2014. 
Tabela 8. Wymagania stawiane w ofertach dla kandydatów z wykształceniem zasadniczym zawodowym z poszczególnych kategorii w klasyfikacji ISCO-08

(odsetek ofert, w których wskazano jako wymóg doświadczenie zawodowe i posiadanie referencji oraz średni oczekiwany staż pracy)

\begin{tabular}{|c|c|c|c|c|c|}
\hline \multirow{2}{*}{$\begin{array}{l}\text { Kod } \\
\text { ISCO- } \\
08\end{array}$} & \multirow[b]{2}{*}{ Grupa zawodowa } & \multicolumn{3}{|c|}{ Doświadczenie zawodowe } & \multirow[b]{2}{*}{$\mathrm{N}$} \\
\hline & & $\%$ ofert & $\begin{array}{l}\text { długość } \\
\text { stażu }\end{array}$ & $\begin{array}{l}\% \text { ofert z } \\
\text { referencjami }\end{array}$ & \\
\hline 8.82 & $\begin{array}{l}\text { operatorzy i monterzy maszyn i urządzeń: } \\
\text { monterzy }\end{array}$ & 70 & 1,9 & 25 & 110 \\
\hline 7.74 & $\begin{array}{l}\text { robotnicy przemysłowi i rzemieślnicy: elektrycy } \\
\text { i elektronicy }\end{array}$ & 64 & 1,7 & 21 & 670 \\
\hline 7.72 & $\begin{array}{l}\text { robotnicy przemysłowi i rzemieślnicy: robotnicy } \\
\text { obróbki metali, mechanicy maszyn i urządzeń }\end{array}$ & 71 & 2,3 & 13 & 1287 \\
\hline 7.73 & $\begin{array}{l}\text { robotnicy przemysłowi i rzemieślnicy: rzemieślni- } \\
\text { cy i robotnicy poligraficzni }\end{array}$ & 57 & 1,9 & 32 & 74 \\
\hline 7.75 & $\begin{array}{l}\text { robotnicy przemysłowi i rzemieślnicy: robotnicy } \\
\text { w przetwórstwie spożywczym, obróbce drewna, } \\
\text { produkcji wyrobów tekstylnych }\end{array}$ & 57 & 2,5 & 27 & 811 \\
\hline 8.81 & $\begin{array}{l}\text { operatorzy i monterzy maszyn i urządzeń: } \\
\text { operatorzy maszyn i urządzeń wydobywczych } \\
\text { i przetwórczych }\end{array}$ & 67 & 2,3 & 18 & 211 \\
\hline 8.83 & $\begin{array}{l}\text { operatorzy i monterzy maszyn i urządzeń: } \\
\text { kierowcy i operatorzy pojazdów }\end{array}$ & 70 & 1,9 & 14 & 1251 \\
\hline 7.71 & $\begin{array}{l}\text { robotnicy przemysłowi i rzemieślnicy: robotnicy } \\
\text { budowlani - z wyłączeniem elektryków }\end{array}$ & 60 & 2,1 & 23 & 1196 \\
\hline 9.94 & $\begin{array}{l}\text { pracownicy przy pracach prostych: pracownicy } \\
\text { przygotowujący posiłki }\end{array}$ & 61 & 1,4 & 22 & 100 \\
\hline 5.51 & $\begin{array}{l}\text { pracownicy usług i sprzedawcy: pracownicy usług } \\
\text { osobistych }\end{array}$ & 60 & 1,5 & 23 & 1006 \\
\hline 9.93 & $\begin{array}{l}\text { pracownicy przy pracach prostych: robotnicy } \\
\text { pomocniczy w górnictwie, przemyśle, } \\
\text { budownictwie i transporcie }\end{array}$ & 69 & 1,7 & 12 & 194 \\
\hline 5.54 & $\begin{array}{l}\text { pracownicy usług i sprzedawcy: pracownicy usług } \\
\text { ochrony }\end{array}$ & 69 & 1,4 & 14 & 149 \\
\hline 9.96 & $\begin{array}{l}\text { pracownicy przy pracach prostych: ładowacze } \\
\text { nieczystości i inni pracownicy przy pracach } \\
\text { prostych }\end{array}$ & 73 & 2,4 & 9 & 47 \\
\hline 4.43 & $\begin{array}{l}\text { pracownicy biurowi: pracownicy do spraw finan- } \\
\text { sowo-statystycznych i ewidencji materiałowej }\end{array}$ & 63 & 1,8 & 23 & 146 \\
\hline 5.52 & pracownicy usług i sprzedawcy: sprzedawcy & 57 & 1,2 & 32 & 677 \\
\hline 3.34 & $\begin{array}{l}\text { technicy i inny średni personel: średni personel } \\
\text { z dziedziny prawa, spraw społecznych, kultury }\end{array}$ & 56 & 0 & 31 & 31 \\
\hline 9.91 & $\begin{array}{l}\text { pracownicy przy pracach prostych: pomoce } \\
\text { domowe i sprzątaczki }\end{array}$ & 75 & 1,2 & 6 & 60 \\
\hline 3.31 & $\begin{array}{l}\text { technicy i inny średni personel: średni personel } \\
\text { nauk fizycznych, chemicznych i technicznych }\end{array}$ & 60 & 2,3 & 29 & 78 \\
\hline 4.42 & pracownicy biurowi: pracownicy obsługi klienta & 57 & 1,1 & 31 & 49 \\
\hline
\end{tabular}

Dane nie sumują się do $100 \%$, ponieważ pracodawcy wskazywali także inne wymagania wobec wykształcenia kandydatów.

Źródło: opracowanie własne na podstawie danych BKL, badanie ofert pracy 2010-2014. 
Analizując podaż ofert pracy, warto jednak zwrócić uwagę na precyzję w formułowaniu oczekiwań w kwestii poziomu wykształcenia kandydatów do pracy (tabela 7). Dokładność opisu zależy od stopnia złożoności stanowiska, na które prowadzona jest rekrutacja, zgodnie z regułą: „im bardziej złożone obowiązki zawodowe w pracy, tym precyzyjniej określone oczekiwania pracodawców" (Kocór i in. 2012, s. 43). Innymi słowy, absolwenci szkół zawodowych mogą aplikować na najlepsze stanowiska dostępne na rynku pracy, pamiętając, że dla pracodawcy formalne, branżowe wykształcenie jest mniej istotne od faktycznych umiejętności, mierzonych latami doświadczenia zawodowego (Kocór i in. 2015).

Bez względu na stanowisko pracy, na które była prowadzona rekrutacja, pracodawcy w ok. $60 \%$ ogłoszeń oczekiwali od kandydatów posiadających wykształcenie zawodowe doświadczenia w wykonywaniu obowiązków odpowiadających oferowanemu stanowisku (tabela 8). Średnia długość wymaganego doświadczenia wahała się od roku do ponad dwóch lat. Najdłuższego stażu pracy wymagano na stanowiskach robotników przemysłowych i rzemieślników oraz operatorów maszyn i urządzeń, najkrótszego - w naborach na pracowników obsługi klienta, sprzedawców i pracowników ochrony. Co interesujące, w procesie rekrutacji na stanowiska z najkrótszym oczekiwanym stażem pracy pracodawcy najczęściej żądali referencji z poprzedniego miejsca pracy. Analogicznie było w przypadku naboru średniego personelu z dziedziny prawa, spraw społecznych i kultury: od osób z wykształceniem zawodowym pracodawcy oczekiwali co prawda doświadczenia zawodowego (dotyczyło to $56 \%$ ofert), przy czym jednak liczyła się dla nich nie długość, lecz jakość stażu pracy, wyrażona w referencjach od byłych pracodawców.

Zatem w procesie rekrutacji poprzez oferty pracy większe szanse na sukces mają te osoby $z$ wykształceniem zawodowym, które mogą udokumentować zatrudnienie przez przynajmniej jednego pracodawcę, najlepiej poparte referencjami. To faworyzowanie "gotowych pracowników" może mieć związek z oczekiwaniem przez pracodawcę realnych korzyści z zatrudnienia tego typu pracowników od pierwszych dni pracy, zwłaszcza że pod względem wymagań kompetencyjnych zatrudniający oczekują przede wszystkim umiejętności wykonywania obowiązków zawodowych niezbędnych na stanowisku, na jakie rekrutują (tabela 9). 
Przed szczegółowym omówieniem wymagań kompetencyjnych warto podkreślić, że w ogłoszeniach o pracę skierowanych do osób z wykształceniem zawodowym sporadycznie pojawiają się wymagania posiadania kompetencji innych niż zawodowe? ${ }^{7}$. Takie zachowanie pracodawców ma związek przede wszystkim ze specyfiką oferowanych stanowisk pracy. Pracodawcy cechują się racjonalnością i od pracowników z wykształceniem zawodowym oczekują przede wszystkim umiejętności zastosowania w praktyce wiedzy zdobytej w toku kształcenia, czyli kompetencji zawodowych. Pozostałe wymagania kompetencyjne również są przemyślane i dopasowane do specyfiki danego stanowiska pracy, np. od monterów oczekuje się przede wszystkim posługiwania się wyobraźnią techniczną, zdolności manualnych czy umiejętności koncentracji. Te same kompetencje są wymagane także na stanowiskach dla robotników obróbki metali, mechaników maszyn i urządzeń, a także rzemieślników i robotników poligraficznych. W przypadku rekrutacji pracowników pomocniczych przygotowujących posiłki liczy się przede wszystkim samodzielność i dyspozycyjność, podobnie jak u pomocy domowych i sprzątaczek. Dyspozycyjność pożądana jest również u sprzedawców, przy czym na tym stanowisku ceniona jest umiejętność współpracy w grupie. Natomiast od przyszłych pracowników obsługi klienta oczekuje się umiejętności uczenia się oraz samodzielności.

Podsumowując, oferty pracy wskazują, że pracodawcy poszukują pracowników z konkretnym zawodem, a im bardziej złożone obowiązki są do niego przypisane, tym większe wymagania stawia się przed kandydatem w procesie rekrutacji. Przy czym w przypadku ofert skierowanych do osób z wykształceniem zawodowym bardziej liczą się doświadczenie i umiejętności zawodowe niż formalne wykształcenie. 


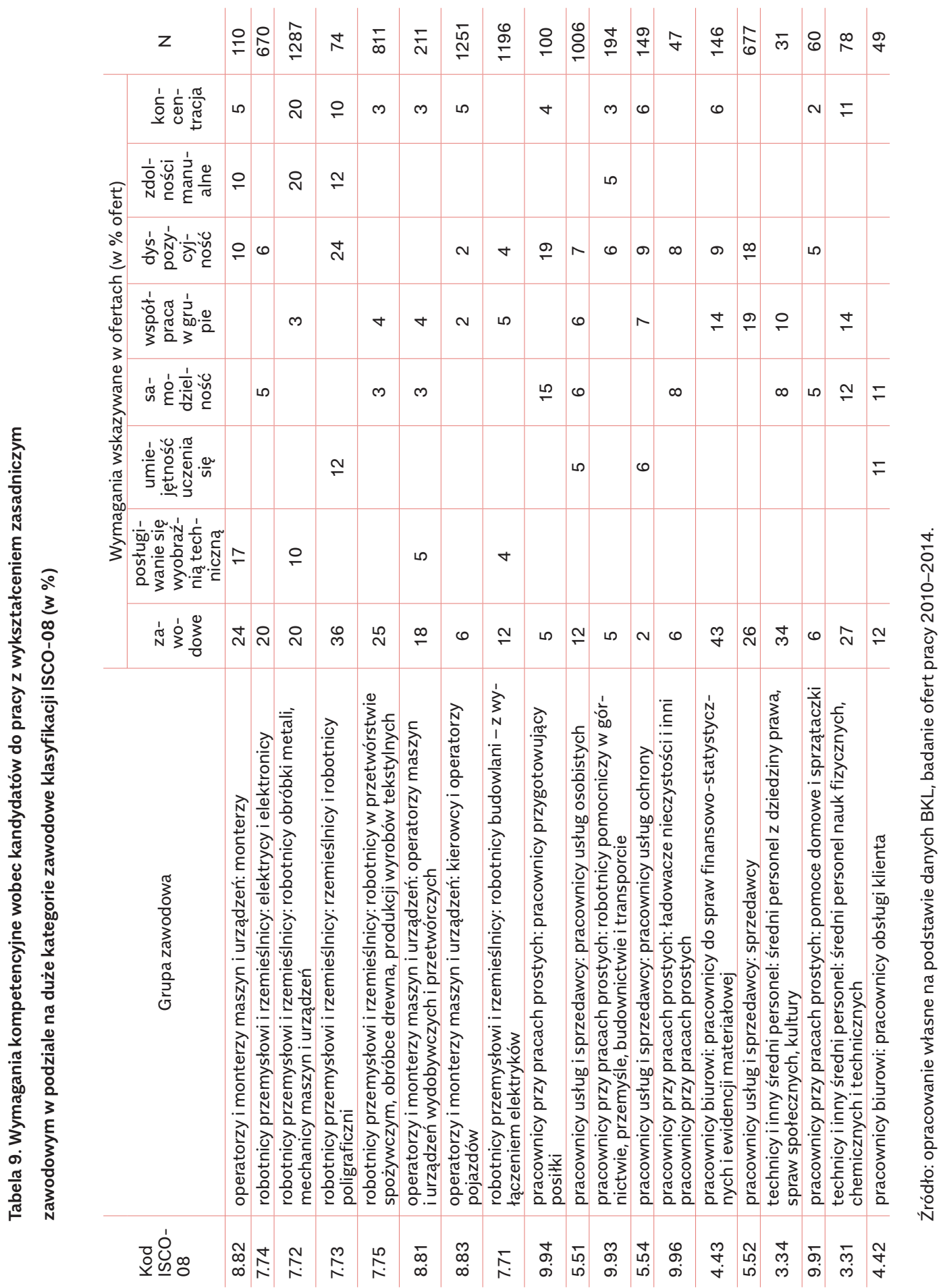




\section{Absolwenci szkół zawodowych na rynku pracy}

\section{Trudniejszy start i szybka dezaktywizacja}

Podejmując działania na rzecz wzrostu zainteresowania kształceniem na poziomie zawodowym, należy nie tylko brać pod uwagę aktualne i przyszłe zapotrzebowanie na kwalifikacje i kompetencje, ale też uwzględniać ocenę dotychczasowego przygotowania i perspektywy, jakie swoim absolwentom dają szkoły zawodowe. Obecna sytuacja osób z wykształceniem zawodowym na rynku pracy, poziom ich zatrudnienia, a także jakość wykonywanej pracy mogą bowiem silnie oddziaływać na wybory edukacyjne młodych ludzi i na oczekiwania rodziców co do poziomu i charakteru wykształcenia swoich dzieci. Choć losy absolwentów szkół zawodowych i ich sytuacja na rynku pracy nie mogą być traktowane jako podstawa pełnej oceny szkolnictwa zawodowego, na pewno są istotnym jej elementem. Dlatego też w tej części rozdziału skupimy się na przedstawieniu sytuacji takich osób, biorąc pod uwagę poziom i charakter ich zatrudnienia, ocenę warunków wykonywanej pracy oraz wyniki samooceny kompetencji. Dla celów tej analizy wykorzystamy wyniki badania ludności Bilansu Kapitału Ludzkiego 2017.

Pierwszą kwestią, jaką należy uwzględnić, jest ogólna sytuacja na rynku pracy osób kończących szkoły zawodowe i odniesienie jej do sytuacji osób mających inne wykształcenie. Sytuację tę dla różnych grup wieku przedstawia tabela 10. Wynika z niej, że z wyjątkiem dwóch młodszych grup wiekowych (18-24 i 25-34 lata) wśród osób z wykształceniem zawodowym odsetek pracujących jest zawsze niższy niż wśród osób mających wykształcenie wyższe, często też niższy niż wśród osób z wykształceniem średnim. Ponadto uwagę zwracają dwie tendencje - wysoki odsetek osób bezrobotnych z wykształceniem zawodowym w najmłodszej grupie wieku (18-24 lata) i wczesna dezaktywizacja zawodowa osób o tym poziomie wykształcenia. Wśród absolwentów szkół zawodowych w wieku 18-24 lata prawie $1 / 3$ to osoby bezrobotne, $12 \%$ to osoby nieaktywne zawodowo, a tylko $57 \%$ to osoby pracujące. Co prawda odsetek bezrobotnych z wykształceniem zawodowym jest już wielokrotnie niższy wśród osób w wieku 25-34 lata, bo wynosi zaledwie $2 \%$, wskazuje to jednak, że osoby te doświadczają relatywnie dużych trudności przy wejściu na rynek pracy. Pozytywną stroną tej sytuacji jest to, że są one raczej przejściowe, co bez wątpienia wiąże się z aktualnie ogólnie niskim poziomem bezrobocia i z dużym zapotrzebowaniem 
na pracowników. Jednak już po 35. roku życia pojawia się dezaktywizacja zawodowa osób, które ukończyły zasadnicze szkoły zawodowe. Wśród osób w wieku 45-54 lata nieaktywnych zawodowo jest już prawie $20 \%$ osób z wykształceniem zawodowym, natomiast z wykształceniem średnim jest to $9 \%$, a z wykształceniem wyższym - jedynie $6 \%$. Przyczyn tej sytuacji można z jednej strony szukać w charakterze pracy wykonywanej przez osoby o różnym poziomie wykształcenia (częściej fizyczna i obciążająca praca wśród osób z wykształceniem zawodowym), z drugiej zaś w nieumiejętności adaptacji do zmieniających się warunków pracy. Potwierdza to analiza odpowiedzi na pytanie dotyczące oceny szans na znalezienie pracy w przypadku jej utraty. Choć wśród ogółu badanych wykształcenie nie różnicuje oceny tych szans, to różnice stają się widoczne wśród osób po 45. roku życia. Osoby z wykształceniem zawodowym mające więcej niż 45 lat swoje szanse na znalezienie podobnej pracy oceniają znacząco niżej niż będące $w$ tym samym wieku osoby z wykształceniem średnim i wyższym. Jak można się spodziewać, dezaktywizacja zawodowa częściej dotyczy kobiet niż mężczyzn - wśród osób w wieku 45-54 lata posiadających wykształcenie zawodowe nieaktywnych jest $26 \%$ kobiet i $14 \%$ mężczyzn. 
Tabela 10. Odsetki osób pracujących, bezrobotnych i nieaktywnych

zawodowo ze względu na wiek i poziom wykształcania

\begin{tabular}{|c|c|c|c|c|c|}
\hline & & \multicolumn{4}{|c|}{ Wykształcenie } \\
\hline & & $\begin{array}{l}\text { zasadnicze } \\
\text { zawodowe }\end{array}$ & średnie & wyższe & ogółem ${ }^{\star *}$ \\
\hline \multirow{3}{*}{ 18-24 lata } & pracujący & 57 & 52 & 57 & 53 \\
\hline & bezrobotni & 31 & 9 & 7 & 12 \\
\hline & nieaktywni & 12 & 40 & 35 & 35 \\
\hline \multirow{3}{*}{ 25-34 lata } & pracujący & 84 & 78 & 84 & 81 \\
\hline & bezrobotni & 2 & 5 & 2 & 3 \\
\hline & nieaktywni & 13 & 17 & 14 & 15 \\
\hline \multirow{3}{*}{ 35-44 lata } & pracujący & 77 & 85 & 92 & 86 \\
\hline & bezrobotni & 5 & 4 & 3 & 4 \\
\hline & nieaktywni & 19 & 11 & 5 & 10 \\
\hline \multirow{3}{*}{ 45-54 lata } & pracujący & 75 & 87 & 92 & 84 \\
\hline & bezrobotni & 6 & 4 & 2 & 4 \\
\hline & nieaktywni & 19 & 9 & 6 & 12 \\
\hline \multirow{3}{*}{ 55-64 lata } & pracujący & 54 & 55 & 76 & 58 \\
\hline & bezrobotni & 2 & 3 & 3 & 2 \\
\hline & nieaktywni & 45 & 42 & 21 & 39 \\
\hline \multirow{3}{*}{ 65-69 lat } & pracujący & 16 & 25 & 36 & 23 \\
\hline & bezrobotni & 1 & 0 & 7 & 1 \\
\hline & nieaktywni & 84 & 75 & 57 & 76 \\
\hline \multirow{3}{*}{ ogółem } & pracujący & 61 & 65 & 84 & 70 \\
\hline & bezrobotni & 5 & 5 & 3 & 4 \\
\hline & nieaktywni & 35 & 30 & 13 & 26 \\
\hline $\mathrm{N}$ & & 1021 & 1509 & 1113 & 3643 \\
\hline
\end{tabular}

* Definicje pracy, bezrobocia i nieaktywności według BAEL, ze względu na małe

liczebności nie uwzględniono osób z wykształceniem niższym niż zawodowe.

** Oznacza udział procentowy danej odpowiedzi dla wszystkich

badanych (tzw. przeciętny profil kolumnowy).

Źródło: BKL, badanie ludności 2017.

W analizie sytuacji osób z wykształceniem zawodowym na rynku pracy warto też uwzględnić inne charakterystyki, takie jak np. forma zatrudnienia i warunki pracy. Pod względem formy zatrudnienia osoby z wykształceniem zawodowym nie różnią się zasadniczo od osób z wykształceniem średnim czy wyższym. Wśród osób z wykształceniem wyższym można znaleźć nieco więcej pracowników zatrudnionych na podstawie umowy o pracę, jednak wiąże się to przede wszystkim z ogólnie wyższym odsetkiem osób pracujących wśród tych, które posiadają wyższe wykształcenie. Ciekawe jest natomiast to, że zatrudnienie na podstawie umowy cywilnoprawnej jest przede wszystkim domeną osób 
z wykształceniem wyższym i średnim, w przypadku których ta forma umowy jest bardzo często łączona z umową o pracę. Osoby z wykształceniem zawodowym takie zatrudnienie podejmują dwukrotnie rzadziej niż osoby z wykształceniem średnim i wyższym. Nie wyróżniają się też - przynajmniej w deklaracjach - pod względem skali zatrudnienia bez formalnej umowy (zatrudnienie na czarno, w szarej strefie). Co prawda $7 \%$ spośród osób z wykształceniem zawodowym zadeklarowało wykonywanie pracy bez formalnej umowy, jednak nie odbiega to znacząco od wyników w innych grupach wykształcenia. Podobny w każdej grupie wykształcenia i raczej niewielki jest również odsetek osób pracujących w ostatnich dwunastu miesiącach za granicą.

Tabela 11. Odsetek osób pracujących na podstawie różnych form zatrudnienia wśród osób

z wykształceniem zawodowym, średnim i wyższym (odsetek wśród osób pracujących)

\begin{tabular}{l|c|c|c|c|c}
\multirow{2}{*}{} & \multicolumn{4}{|c}{ Wykstałcenie } \\
\cline { 2 - 5 } & $\begin{array}{l}\text { zasadnicze } \\
\text { zawodowe }\end{array}$ & średnie & wyższe & ogółem & N \\
\hline prowadzi samodzielną działalność gosp./roln. & 21 & 19 & 19 & 19 & 493 \\
\hline obecnie zatrudniony na podstawie umowy o pracę & 68 & 69 & 82 & 73 & 1863 \\
\hline $\begin{array}{l}\text { w minionych 12 miesiącach zatrudniony } \\
\text { na umowę o dzieło lub zlecenie }\end{array}$ & 6 & 16 & 18 & 14 & 360 \\
\hline $\begin{array}{l}\text { w minionych 12 miesiącach zatrudniony } \\
\text { na podstawie umowy nieformalnej }\end{array}$ & 7 & 8 & 5 & 6 & 165 \\
\hline $\begin{array}{l}\text { w minionych 12 miesiącach pomagał } \\
\text { nieodpłatnie w rodzinnej działaln. gosp./rol. }\end{array}$ & 15 & 15 & 9 & 13 & 327 \\
\hline $\begin{array}{l}\text { w minionych 12 miesiącach pracował } \\
\text { zarobkowo za granicą }\end{array}$ & 4 & 4 & 2 & 3 & 80
\end{tabular}

Źródło: BKL, badanie ludności 2017.

Osoby z wykształceniem zawodowym i średnim istotnie rzadziej niż te z wykształceniem wyższym deklarują, że wykonywana przez nie praca jest zgodna z posiadanym wykształceniem. Różnice te występują wśród badanych z wszystkich grup wieku, ale zwiększają się w grupach nieco starszych, czyli wśród osób o dłuższym stażu pracy. Jest to związane z tym, że w przypadku osób z wykształceniem wyższym wraz z kolejnymi latami pracy znacząco wzrasta odsetek osób wykonujących pracę odpowiadającą zdobytemu wykształceniu, natomiast wśród osób z wykształceniem zawodowym, choć następuje poprawa dopasowania, to jednak jest ona niewielka. Prawidłowość tę zaobserwowano już 
w poprzednich edycjach BKL (2010-2014), obecne badania wskazują, że występuje ona nadal.

Wykres 4. Ocena zgodności wykonywanej pracy

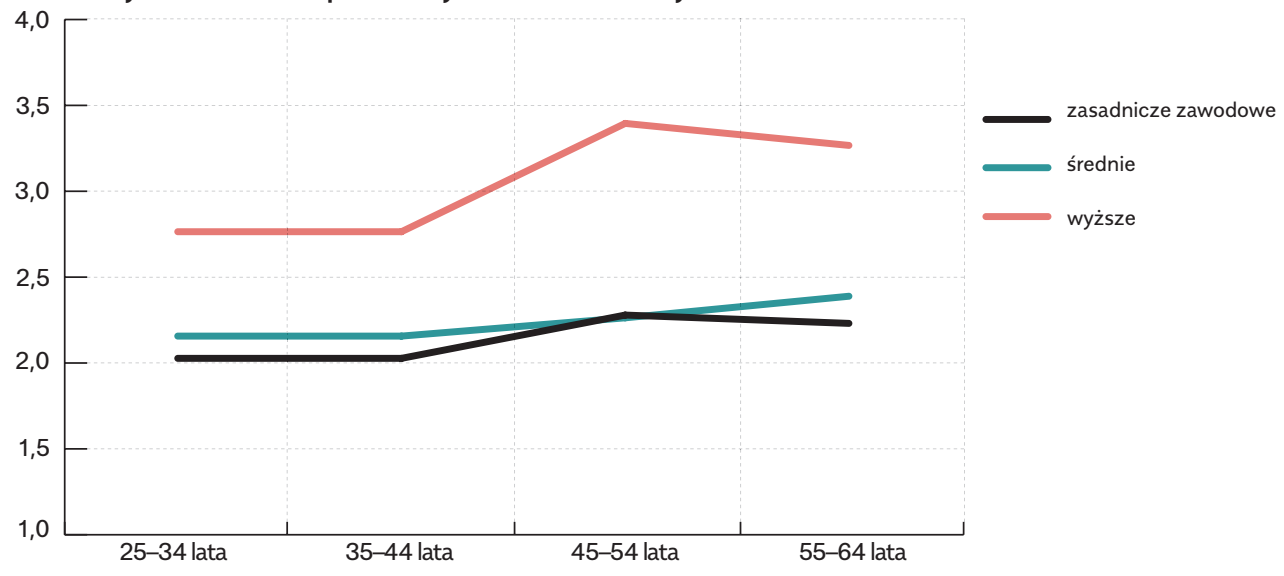

z wykształceniem a poziom wykształcenia badanych

* Skala 1-4: 1 - zdecydowanie nie, 2 - raczej nie, 3 - raczej tak, 4 - zdecydowanie tak. Źródło: BKL, badanie ludności 2017.

Pośrednim wskaźnikiem jakości przygotowania do przyszłej pracy, jakie młodzi ludzie uzyskują w szkołach, może być też ocena przydatności zdobytych w nich wiedzy i umiejętności. Pod tym względem osoby z wykształceniem zawodowym są zbliżone do absolwentów szkół średnich - najczęściej twierdzą, że wiedza i umiejętności, jakie wynieśli ze szkół, są mało przydatne w pracy. Różnią się natomiast znacznie od osób z wykształceniem wyższym, które najczęściej twierdzą, że kompetencje, jakie uzyskały w szkołach, są w tej pracy w miarę przydatne (wykres 5). Warto też zwrócić uwagę, że wśród osób z wykształceniem wyższym ocena przydatności wiedzy i umiejętności wyniesionych ze szkół jest wyższa w starszych grupach wieku, natomiast wśród osób z wykształceniem zawodowym pozostaje na podobnym poziomie w każdej grupie wieku. Może to być związane ze wskazywanym wcześniej wzrostem dopasowania zawodowego w kolejnych latach kariery obserwowanym wśród osób z wykształceniem wyższym - ponieważ w starszych grupach wieku wzrasta odsetek wykonujących pracę zgod- 
ną z wykształceniem, rośnie też odsetek uznających przydatność kompetencji zdobytych $w$ trakcie edukacji.

Wykres 5. Ocena przydatności wiedzy i umiejętności

wyniesionych ze szkół a poziom wykształcenia badanych

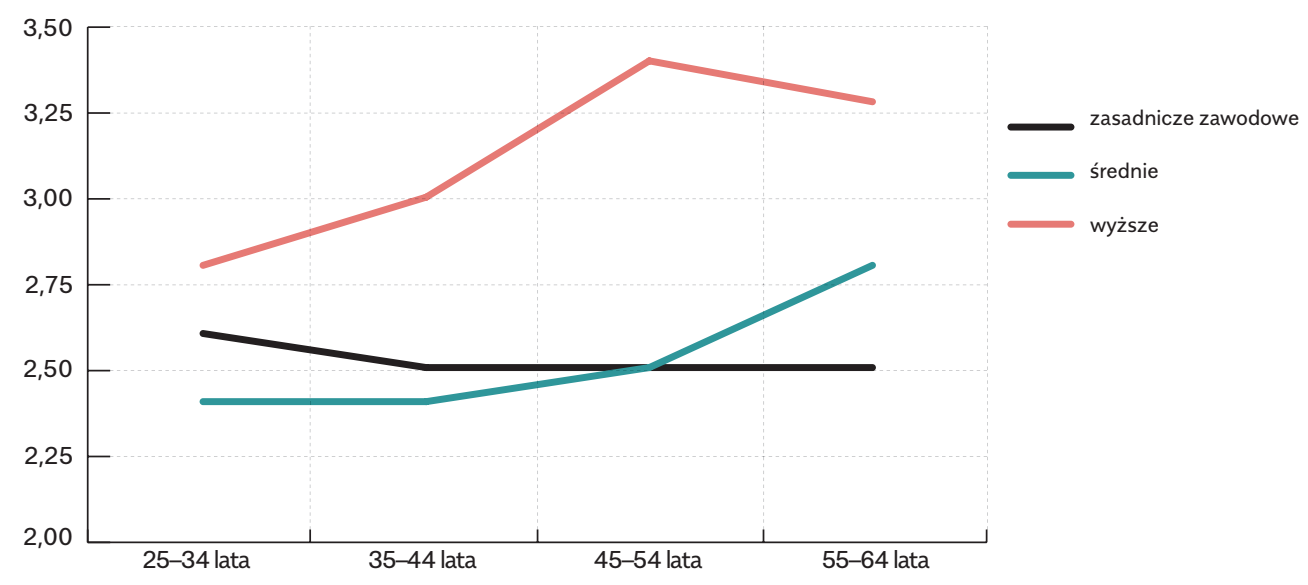

* Skala 1-4: 1 - zupełnie nieprzydatne, 2 - mało przydatne,

3-w miarę przydatne, 4 - bardzo przydatne.

Źródło: BKL 2017, badanie ludności.

Osoby pracujące z wykształceniem zawodowym zarabiają znacznie mniej niż osoby, które zdobyły wykształcenie średnie lub wyższe. Według badań BKL 2017 przeciętne zarobki pracujących osób z wykształceniem zawodowym w 2017 r. wynosiły 2233 zł netto, osoby z wykształceniem średnim zarabiały średnio 2543 zł netto, a osoby z wykształceniem wyższym 3623 zł netto (Czarnik i in. 2018) ${ }^{8}$. Należy

8 W tym czasie przeciętne miesięczne wynagrodzenie netto wyniosło 2758 zł (III kwartał 2017 r.). W odróżnieniu od wskaźnika przeciętnych wynagrodzeń w sektorze przedsiębiorstw publikowanego przez GUS, dane BKL uwzględniają dochody z pracy deklarowane również przez pracowników administracji publicznej, osoby samozatrudnione, pracujące dla podmiotów zatrudniających poniżej 10 osób, a także osoby wykonujące pracę w ramach umów cywilnoprawnych. Przeciętne wynagrodzenie brutto w sektorze przedsiębiorstw (tzw. średnia krajowa) w 2017 r. wynosiło 4513 zł brutto (ok. 3200 zł netto). Za: bit.ly/2Xfj4kr [dostęp: 2.11.2018]. Ustawowa płaca minimalna wynosiła w czasie badania 2000 zł brutto (1459 zł netto). 
dodać, że inną zmienną silnie różnicującą poziom zarobków była płeć - przeciętnie zarobki kobiet stanowiły $76 \%$ przeciętnych zarobków mężczyzn, przy czym w obrębie poszczególnych kategorii wykształcenia proporcja ta wynosiła $68 \%$ (tabela 12). Pod względem zarobków w najgorszej sytuacji znajdują się kobiety z wykształceniem zawodowym i to niezależnie od wieku - czy inaczej - stażu pracy. Choć zarobki kobiet z tym poziomem wykształcenia są najniższe w najmłodszej grupie wieku, to staż pracy w zasadzie nie wpływa na ich wzrost. Podobną sytuację obserwujemy wśród kobiet z wykształceniem średnim - wśród nich również zarobki są podobne w każdej kategorii wieku. Natomiast wśród kobiet $z$ wykształceniem wyższym widoczny jest wyraźny wzrost zarobków w każdej kolejnej grupie wieku. Wyraźny wpływ stażu pracy na wysokość wynagrodzenia dotyczy jednak nie tylko kobiet z wykształceniem wyższym, lecz także mężczyzn, czyli ogólnie - całej kategorii osób o tym poziomie wykształcenia (wykres 6).

Wykres 6. Przeciętne miesięczne zarobki netto a wykształcenie (PLN)*

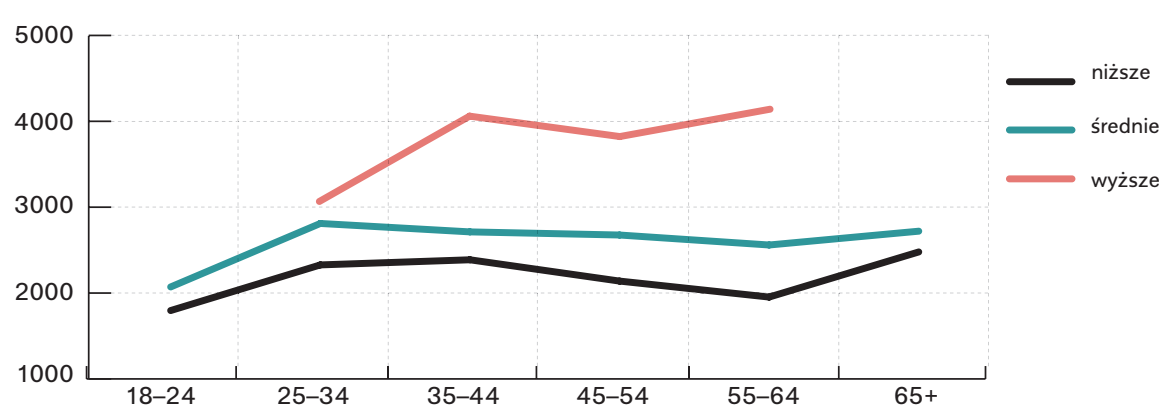

* Średnia obcięta 5\% - z analiz wykluczono po 5\% najniższych i najwyższych wartości.

Odpowiedzi osób pracujących. Zarobki podano wyłącznie dla grup respondentów, których liczebność ważona w danej komórce wynosiła co najmniej 20 osób. Źródło: Czarnik i in. 2018.

Osoby z wykształceniem zawodowym nie tylko zarabiają mniej niż osoby posiadające wykształcenie co najmniej średnie, ale też niżej oceniają finansową wartość swojej pracy, określając swoje oczekiwania finansowe. Sprawdzeniem takich oczekiwań było w badaniach ludności 
BKL 2017 zadanie pytania dotyczącego warunków finansowych podjęcia przez respondenta pracy w sytuacji, gdyby utracił obecną pracę i musiał znaleźć inną. Jak pokazano na wykresie 7, zarówno pod względem płacy minimalnej zadowalającej, jak i bardzo zadowalającej oczekiwania pracujących obecnie osób z wykształceniem zawodowym są znacząco niższe nie tylko od będących w podobnej sytuacji osób z wykształceniem wyższym, ale i średnim. Znów widać wyraźnie, że o ile oczekiwania finansowe osób $z$ wykształceniem wyższym będących w różnym wieku wyraźnie się różnią, o tyle w przypadku osób z wykształceniem zawodowym są one zasadniczo zbliżone. Duży wpływ na formułowanie tych oczekiwań mają zapewne faktyczne zarobki badanych, na podstawie których dokonuje się szacunków wartości pracy własnej i możliwych zarobków w innym niż obecne miejscu zatrudnienia.

Wykres 7. Oczekiwania płacowe osób pracujących

o różnym poziomie wykształcenia (w PLN)

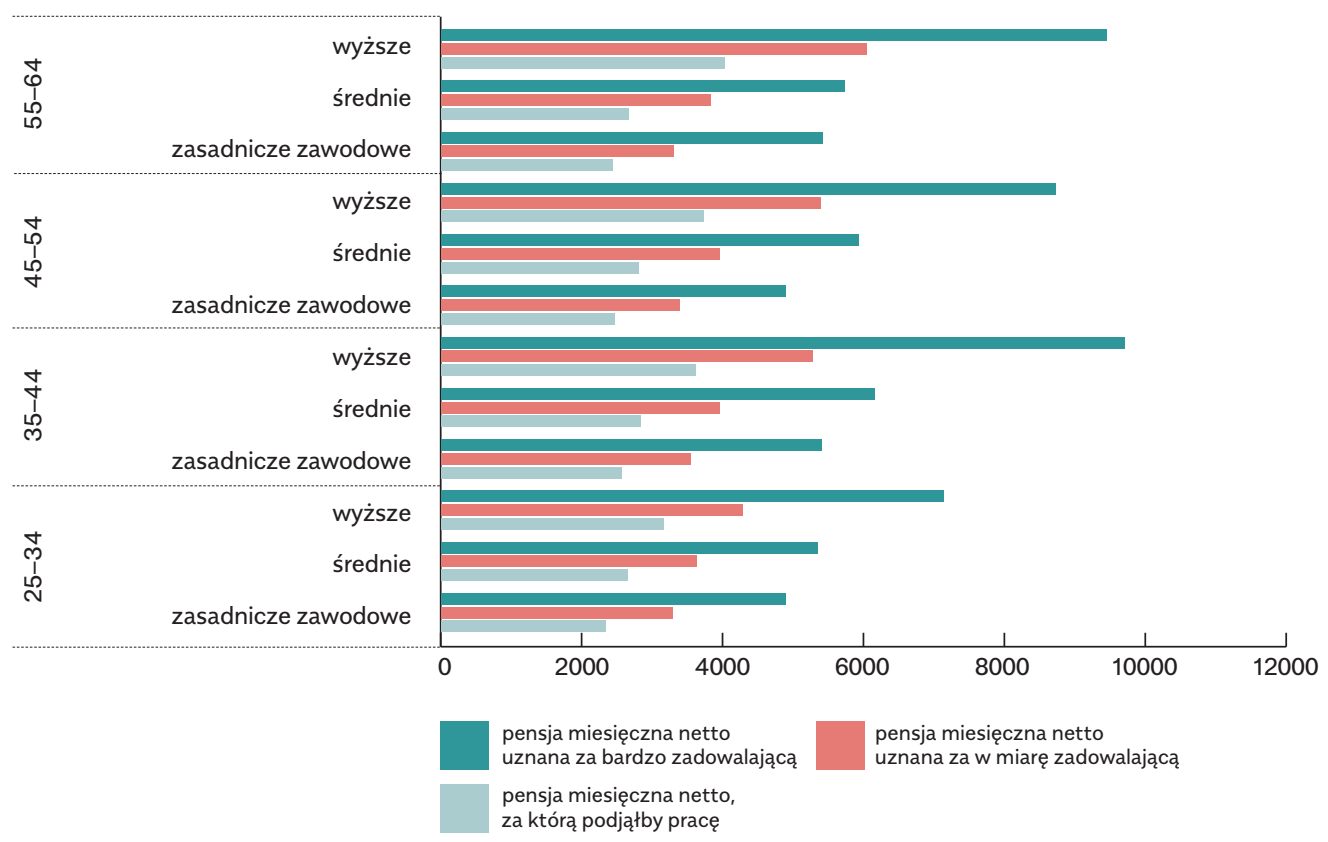

Źródło: BKL 2017, badanie ludności. 


\section{Samoocena kompetencji}

Ostatnią kwestią, na jaką chcemy zwrócić uwagę, porównując osoby z wykształceniem zawodowym z osobami o innym poziomie wykształcenia, jest samoocena kompetencji uniwersalnych czy transferowalnych (Becker 1964), czyli takich, które są przydatne na każdym stanowisku pracy i stanowią podstawę wykorzystania kompetencji stricte zawodowych. W badaniach BKL uwzględnia się kilkanaście kategorii takich kompetencji czy też, szerzej- umiejętności czy dyspozycji, które są istotne z perspektywy funkcjonowania jednostki na rynku pracy. Do takich umiejętności należą np. szczegółowo analizowane w badaniach PIAAC umiejętności matematyczne, związane z rozumieniem tekstu czy z posługiwaniem się technologiami informacyjno-komunikacyjnymi. Zakres badanych w BKL kategorii kompetencji jest znacznie szerszy, jednak w przeciwieństwie do badań PIAAC bada się je nie przez dokonanie faktycznej oceny ich poziomu na podstawie wyników respondentów w testach kompetencyjnych, lecz na podstawie deklaracji badanych. Nie jest to więc ocena obiektywna, ale subiektywna czy, inaczej - samoocena. Takie podejście, choć nie zastępuje obiektywnego pomiaru, pozwala uwzględnić w badaniu większą liczbę umiejętności i predyspozycji, które są istotne z punktu widzenia tego, jak jednostka może funkcjonować na rynku pracy (Strzebońska, Dobrzyńska 2011). 
Tabela 12. Samoocena kompetencji osób pracujących o różnym poziomie wykształcenia

\begin{tabular}{|c|c|c|c|c|c|}
\hline & \multicolumn{3}{|c|}{ Wykształcenie } & \multirow{2}{*}{$\begin{array}{c}\text { Różnica } \\
\text { wyższe- } \\
\text { zawodowe }\end{array}$} & \multirow{2}{*}{$\mathrm{N}$} \\
\hline & zawodowe & średnie & wyższe & & \\
\hline analiza informacji i wyciąganie wniosków & 3,3 & 3,61 & 4,14 & 0,84 & 2679 \\
\hline uczenie się nowych rzeczy & 3,53 & 3,78 & 4,12 & 0,59 & 2684 \\
\hline $\begin{array}{l}\text { posługiwanie się komputerem, tabletem, } \\
\text { smartfonem }\end{array}$ & 2,65 & 3,59 & 4,14 & 1,49 & 2688 \\
\hline $\begin{array}{l}\text { obsługa specjalistycznych programów } \\
\text { komputerowych }\end{array}$ & 1,78 & 2,73 & 3,42 & 1,64 & 2687 \\
\hline $\begin{array}{l}\text { obsługa maszyn, narzędzi i urządzeń } \\
\text { technicznych }\end{array}$ & 3,24 & 3,27 & 3,15 & $-0,09$ & 2679 \\
\hline $\begin{array}{l}\text { montaż i naprawa maszyn i urządzeń } \\
\text { technicznych }\end{array}$ & 2,71 & 2,55 & 2,14 & $-0,57$ & 2681 \\
\hline wykonywanie prostych rachunków & 3,54 & 3,93 & 4,26 & 0,72 & 2688 \\
\hline $\begin{array}{l}\text { wykonywanie zaawansowanych obliczeń } \\
\text { matematycznych }\end{array}$ & 2,12 & 2,73 & 3,2 & 1,08 & 2688 \\
\hline zdolności artystyczne & 2,3 & 2,54 & 2,76 & 0,46 & 2686 \\
\hline sprawność fizyczna & 3,4 & 3,49 & 3,45 & 0,05 & 2686 \\
\hline radzenie sobie w sytuacjach stresujących & 3,42 & 3,58 & 3,75 & 0,33 & 2686 \\
\hline $\begin{array}{l}\text { gotowość do brania na siebie odpowie- } \\
\text { dzialności }\end{array}$ & 3,77 & 3,97 & 4,17 & 0,4 & 2687 \\
\hline pomysłowość, kreatywność & 3,45 & 3,71 & 3,95 & 0,5 & 2686 \\
\hline zarządzanie czasem i terminowość & 3,65 & 3,8 & 4,03 & 0,38 & 2686 \\
\hline samodzielna organizacja pracy & 3,84 & 3,99 & 4,22 & 0,38 & 2686 \\
\hline praca w grupie & 3,82 & 3,91 & 4,02 & 0,2 & 2681 \\
\hline łatwe nawiązywanie kontaktów z luźmi & 3,96 & 4,02 & 4,09 & 0,13 & 2688 \\
\hline $\begin{array}{l}\text { bycie komunikatywnym i jasne przekazy- } \\
\text { wanie myśli }\end{array}$ & 3,81 & 3,95 & 4,14 & 0,33 & 2687 \\
\hline $\begin{array}{l}\text { współpraca z osobami różnych narodo- } \\
\text { wości }\end{array}$ & 2,86 & 3,2 & 3,46 & 0,6 & 2608 \\
\hline $\begin{array}{l}\text { praca administracyjna i prowadzenie } \\
\text { dokumentacji }\end{array}$ & 2,21 & 3,07 & 3,76 & 1,55 & 2679 \\
\hline koordynowanie pracy innych osób & 2,86 & 3,3 & 3,64 & 0,78 & 2667 \\
\hline rozwiązywanie konfliktów między ludźmi & 3,1 & 3,37 & 3,58 & 0,48 & 2677 \\
\hline $\begin{array}{l}\text { biegłe posługiwanie się jęz. polskim } \\
\text { w mowie i piśmie }\end{array}$ & 3,37 & 3,82 & 4,22 & 0,85 & 2687 \\
\hline gotowość do częstych wyjazdów & 2,81 & 3,08 & 3,22 & 0,41 & 2682 \\
\hline $\begin{array}{l}\text { gotowość do pracy w nietypowych } \\
\text { godzinach }\end{array}$ & 3,25 & 3,3 & 3,23 & $-0,02$ & 2673 \\
\hline
\end{tabular}

* Skala 1-5: 1 - niska, 2 - podstawowa, 3-średnia, 4-wysoka,

5 - bardzo wysoka. Szarym kolorem zaznaczono pozycje, w przypadku

których różnice są nieistotne statystycznie. W pozostałych pozycjach różnice

istotne statystycznie $(\mathrm{p}<0,001)$, test median dla prób niezależnych.

Źródło: BKL, badanie ludności 2017.

Jak pokazano w tabeli 12, w przypadku zdecydowanej większości kompetencji i dyspozycji osoby z wykształceniem zawodowym oceniają 
się znacznie gorzej nie tylko od tych, które mają wykształcenie wyższe, ale także od osób z wykształceniem średnim. Badani z wykształceniem zawodowym najsłabiej w porównaniu do osób z wykształceniem wyższym oceniają swoje kompetencje cyfrowe oraz biurowo-administracyjne, związane z umiejętnością tworzenia dokumentacji, załatwiania spraw administracyjnych. O ile w przypadku większości kompetencji osoby z wykształceniem zawodowym oceniają swoje umiejętności jako średnie i więcej niż średnie, o tyle w przypadku nieco bardziej zaawansowanych umiejętności informatycznych czy matematycznych uznają swoje umiejętności za podstawowe. Nie jest to jednak zaskakujące, jeśli weźmie się pod uwagę zarówno program kształcenia w szkołach zawodowych, jak i charakter pracy wykonywanej przez osoby zatrudnione na stanowiskach adekwatnych do tego poziomu wykształcenia. Dostępne badania pokazują bowiem, że tym, co szczególnie sprzyja rozwojowi danej kategorii kompetencji, jest ich wykorzystywanie w pracy (Palczyńska, Rynko 2013; Rynko 2013). Choć na podstawie tych wyników nie można jednoznacznie twierdzić, czy rzeczywiste kompetencje uniwersalne osób z wykształceniem zawodowym są niższe od kompetencji osób o innym poziomie wykształcenia, czy może raczej niższa jest ich samoocena, to za pierwszą interpretacją przemawia zgodność wyników uzyskanych w BKL z wynikami badania PIAAC (Palczyńska 2013). Badania te pokazują, że osoby z wykształceniem zawodowym zdecydowanie gorzej wypadają w testach oceny kompetencji kluczowych (tamże). Co istotne, zależność między poziomem wykształcenia a samooceną kompetencji pozostaje znaczna $\mathrm{i}$ istotna także przy kontroli wieku.

Niewielka przewaga osób z wykształceniem zawodowym jest natomiast widoczna w przypadku oceny umiejętności obsługi i montażu urządzeń technicznych oraz gotowości do pracy w nietypowych godzinach. Generalnie osoby z wykształceniem zawodowym najlepiej oceniają swoje umiejętności w zakresie łatwości nawiązywania kontaktów z ludźmi, samodzielnej organizacji pracy, pracy w grupie, bycia komunikatywnym i jasnego przekazywania myśli oraz brania odpowiedzialności za wykonywane zadania zawodowe. Co istotne, to właśnie te kompetencje są szczególnie cenione przez pracodawcówi-jak wskazywaliśmy wcześniej - często uznawane za deficytowe. Wskazywałoby to, że albo oceny pracowników są nieco zawyżone w stosunku do faktycznych umiejętności, albo że pracodawcy oczekują, aby te kompetencje były rozwinięte na jeszcze wyższym poziomie. 


\section{Wykształcenie zawodowe w kontekście rynku pracy - podsumowanie}

Wyzwania społeczne i demograficzne, które obserwujemy obecnie, w szczególności niż demograficzny czy boom edukacyjny związany z wysokim odsetkiem osób studiujących, mogą definiować polski rynek pracy równie mocno także w kolejnych latach. Wyzwania te, w powiązaniu z niskim bezrobociem, które obecnie obserwujemy, przekładają się na wysokie zapotrzebowanie na pracowników o zawodowym profilu wykształcenia, utrzymujące się w gospodarce od kilku lat.

Mimo to przytoczone w tym rozdziale wyniki badania pokazują, że wielu młodych ludzi z wykształceniem zawodowym nadal napotyka na duże trudności przy podejmowaniu pierwszej pracy. Wynika to z faktu, że kompetencje, jakich oczekują od nich pracodawcy, trudno zdobyć wyłącznie w szkole, niezbędne dla ich rozwinięcia jest doświadczenie zawodowe. Dlatego w oczekiwaniach pracodawców rekrutujących na niższe stanowiska tak wysoką pozycję zajmuje doświadczenie, co dobrze potwierdzają opisane w tym rozdziale kryteria i wzory rekrutacyjne.

Pracodawcy podkreślają braki kompetencyjne, które obserwują u absolwentów szkół zawodowych w zakresie kompetencji zarówno zawodowych, jak i ogólnych. Z jednej strony należy podkreślić, że deficyt kompetencji ogólnych, tj. umiejętności samoorganizacyjnych czy interpersonalnych, w opinii pracodawców stanowiący istotną słabość $w$ tej grupie zawodów, jest barierą, której niwelowania, z ekonomicznej racjonalności, trudno wymagać od pracodawców. $Z$ drugiej zaś sami pracownicy z wykształceniem zawodowym umiejętności interpersonalne i zdolność samoorganizacji postrzegają jako swoje relatywnie najsilniejsze strony, co na pewno nie jest czynnikiem skłaniającym do dalszego ich rozwijania. Poszerzanie tych kompetencji jest więc zgodnie z klasyczną koncepcją Beckera nieopłacalne dla pracodawców, zaś pracownicy nie widzą potrzeby ich zwiększania, ponieważ uznają, że dysponują nimi w wystarczającym zakresie. Można więc uznać, że na ten obszar należy zwrócić szczególną uwagę zarówno w procesie kształcenia w szkołach zawodowych, jak i w programach wspierających dalszy rozwój ich absolwentów.

W kontekście dużo wyższego niż w przypadku absolwentów szkół wyższych i utrzymującego się w trakcie kolejnych lat kariery zawodowej niedopasowania wykonywanej pracy do kwalifikacji uzyskanych przez absolwentów szkół zawodowych, na uwagę zasługują też profile 
kształcenia w tych szkołach i ich powiązanie z bieżącymi i przyszłymi potrzebami rynku pracy. Naturalnie dynamika zmian na rynku pracy, pojawianie się nowych zawodów, zmienianie się charakteru pracy na istniejących stanowiskach są czynnikami silnie utrudniającymi kształcenie "pod potrzeby" - zwłaszcza przyszłe - pracodawców. Niemniej jednak zaprezentowane tutaj dane należy potraktować jako kolejny głos w dyskusji nad profilami kształcenia w szkołach zawodowych i ich dopasowaniem do zapotrzebowania gospodarki na kwalifikacje. Niepokojące są też dane pokazujące niską ocenę przydatności wiedzy i umiejętności wyniesionych ze szkoły wśród absolwentów szkół zawodowych.

Wspomniana dynamika rynku pracy i spodziewane zmiany w strukturze przyszłego zapotrzebowania na kwalifikacje i kompetencje stanowią dla kształcenia zawodowego duże wyzwanie. Obecny popyt na robotników wykwalifikowanych, stymulowany silnie głównie przez rozwój sektora budowlanego, zgodnie z prognozami CEDEFOP (Country Forecast... 2015) może się znacznie obniżyć. Do 2025 r. spodziewany jest raczej wzrost możliwości podejmowania pracy na stanowiskach wymagających wysokich kwalifikacji (ISCED-97, poziom 5 i 6), a nie na stanowiskach dopasowanych do niskich kwalifikacji (ISCED-97, poziom 1 i 2). Sytuacja ta może stawiać absolwentów szkół zawodowych przed kolejnymi wyzwaniami i jednocześnie potwierdzać jeszcze raz konieczność wyposażenia ich w takie kompetencje, które będą pozwalały im dobrze adaptować się do zachodzących zmian.

Choć bez wątpienia kształcenie zawodowe jest niezwykle ważnym ogniwem systemu edukacji, a jego rola w przygotowaniu wykwalifikowanych kadr gospodarki powinna być wzmacniana, zaprezentowane w tym rozdziale dane trudno uznać za pozwalające na to, aby wystawić mu dobrą ocenę. Bez tej dobrej oceny trudno zaś odpowiedzialnie zachęcać młodych ludzi do podejmowania kształcenia $w$ tym typie szkół, budować ich silną pozycję w społecznej świadomości i sprawiać, że wybór tej ścieżki rozwoju zawodowego będzie miał charakter pozytywny, a nie negatywny. 